MICHELE JOANA ALVES

\title{
EFEITO DA CAQUEXIA ASSOCIADA AO CÂNCER EM COMPONENTES DA MATRIZ EXTRACELULAR DO TECIDO \\ ADIPOSO
}

Dissertação apresentada ao Departamento de Biologia Celular e do Desenvolvimento do Instituto de Ciências Biomédicas da Universidade de São Paulo, para obtenção do Título de Mestre em Ciências. 
MICHELE JOANA ALVES

\section{EFEITO DA CAQUEXIA ASSOCIADA AO CÂNCER EM COMPONENTES DA MATRIZ EXTRACELULAR DO TECIDO ADIPOSO}

Dissertação apresentada ao Departamento de Biologia Celular e do Desenvolvimento do Instituto de Ciências Biomédicas da Universidade de São Paulo, para obtenção do Título de Mestre em Ciências.

Área de concentração: Biologia Celular e Tecidual Orientadora: Profa Dra a Marília Cerqueira Leite Seelaender

Versão original 
DADOS DE CATALOGAÇÃO NA PUBLICAÇÃO (CIP)

Serviço de Biblioteca e Informação Biomédica do

Instituto de Ciências Biomédicas da Universidade de São Paulo

reprodução não autorizada pelo autor

Alves, Michele Joana.

Efeito da caquexia associada ao câncer em componentes da matriz extracelular do tecido adiposo / Michele Joana Alves. -- São Paulo, 2011.

Orientador: Marília Cerqueira Leite Seelaender.

Dissertação (Mestrado) - Universidade de São Paulo. Instituto de Ciências Biomédicas. Departamento de Biologia Celular e do

Desenvolvimento. Área de concentração: Biologia Celular e Tecidual. Linha de pesquisa: Tecido adiposo e metabolismo lipidico na caquexia associada ao câncer.

Versão do título para o inglês: Effects of cancer cachexia on the components of the adipose tissue extracellular matrix.

Descritores: 1. Tecido adiposo 2. Matriz extracelular 3. Caquexia associada ao câncer 4. Fibrose I. Seelaender, Marília Cerqueira Leite II. Universidade de São Paulo. Instituto de Ciências Biomédicas.

Programa de Pós-Graduação em Biologia Celular e Tecidual III. Título. 
Candidato(a):

Título da Dissertação:

Orientador(a):
Michele Joana Alves.

Efeito da caquexia associada ao câncer em componentes da matriz extracelular do tecido adiposo.

Marília Cerqueira Leite Seelaender.

A Comissão Julgadora dos trabalhos de Defesa da Dissertação de Mestrado, em sessão pública realizada a considerou
( ) Aprovado(a)
( ) Reprovado(a)

Examinador(a): Nome completo:

Instituição:

Examinador(a): Nome completo:

Instituição:

Presidente: $\quad$ Nome completo:

Instituição: 
Decl. CEPSH.043/2011

\section{E C L A R A Ç Ã O}

Em adendo ao Parecer PARECER 788/CEP, datado de 13.06.07, por solicitação da Profa. Dra. Marilia Cerqueira Leite Seelaender, responsável pelo Projeto: "Influência das citocinas pró- e antiinflamatórias no tecido adiposo branco. Possível interação adipócito e infiltrado mononuclear", informo que a aluna Michele Joana Alves, faz parte do referido projeto.

São Paulo, 10 de agosto de 2011.

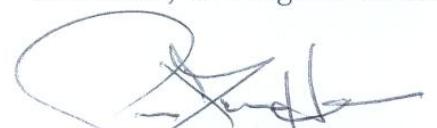

Prof. Dr. Paolo M.A Zanotto

Coordenador da Comissão de Ética em Pesquisas com Seres Humanos - ICB/USP

Comissão de Ética em Pesquisa com Seres Humanos do Instituto de Ciências Biomédicas - USP Aprovada pela Comissão Nacional de Ética em Pesquisa - CONEP, em 10 de fevereiro de 1998 
UNIVERSIDADE DE SÃO PAULO

INSTITUTO DE CIÊNCIAS BIOMÉDICAS

Cidade Universitária "Armando de Salles Oliveira"

Av. Prof. Lineu Prestes, 2415 - cep. 05508-000 Săo Paulo, SP - Brasi

Telefone :(55) (11) 3091.7733 telefax : (55) (11) 3091-7438

e-mail: cep@ icb.usp.br

São Paulo, 13 de junho de 2007.

\section{PARECER 788/CEP}

Prezada Senhora

Atendendo sua solicitação, a Comissão de Ética em Pesquisas com Seres Humanos do ICB, em sua $76^{a}$ reunião, realizada em 13.06.07, analisou o projeto de sua responsabilidade intitulado: "Influência das citocinas pró- e antiinflamatórias no tecido adiposo branco. Possível interação adipócito e infiltrado mononuclear".

Informo a V.Sa. que, após análise e discussão, o referido projeto foi aprovado por esta Comissão, condicionada a reformulação do Termo de Consentimento Livre e Esclarecido, para proteção do grupo controle. Modelo anexo.

Lembramos que cabe ao pesquisador elaborar e apresentar a este Comitê, relatórios anuais (parciais ou final), de acordo com a resolução 196/06 do Conselho Nacional da Saúde, item IX.2 letra c.

O primeiro relatório deverá ser encaminhado à Secretaria deste CEP em 13 de junho de 2008.

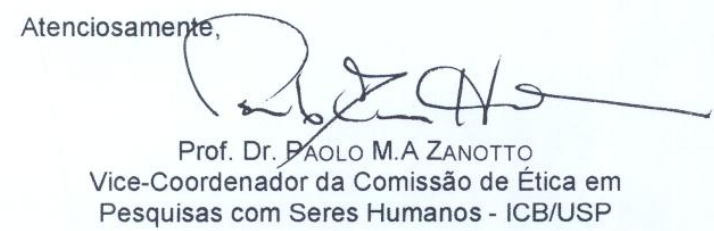

IIma. Sra

MARILIA CERQUEIRA L.SEELAENDER

Departamento de Biologia Celular e do Desenvolvimento

Instituto de Ciências Biomédicas -USP

\footnotetext{
Comissão de Ética em Pesquisa com Seres Humanos do Instituto de Ciências Biomédicas / USP Aprovada pela Comissão Nacional de Ética em Pesquisa - CONEP, em 10 de fevereiro de 1998.
} 
São Paulo, 17 de setembro de 2007.

$I l^{m o(a)} \cdot S^{(a)}$.

Profa. Dra. Marília Cerqueira Leite Seelaender

Grupo de Biologia Molecular da Célula

Departamento de Biologia Celular e do Desenvolvimento

Instituto de Ciências Biomédicas I

UNIVERSIDADE DE SÃO PAULO

REFERENTE: Projeto de Pesquisa "Influência das citocinas pró e antiinflamatórias no tecido adiposo branco. Possível interação entre adipócito e infiltrado mononuclear" - Co-Autor(es): Alex Shimura Yamashita; Paulo Sérgio Martins Alcântara - Registro CEP-HU/USP: 752/07 - SISNEP CAAE: 0031.0.198.019-07

Prezado(a) Senhor(a)

O Comitê de Ética em Pesquisa do Hospital Universitário da Universidade de São Paulo, em reunião ordinária realizada no dia 14 de setembro de 2007, analisou o projeto de pesquisa acima citado, considerando-o como APROVADO, bem como, seu Termo de Consentimento Livre e Esclarecido.

Lembramos que cabe ao pesquisador elaborar e apresentar a este Comitê, relatórios anuais (parciais ou final, em função da duração da pesquisa), de acordo com a Resolução 196/96 do Conselho Nacional de Saúde, item IX.2 letra c.

O primeiro relatório está previsto para 14 de setembro de 2008.

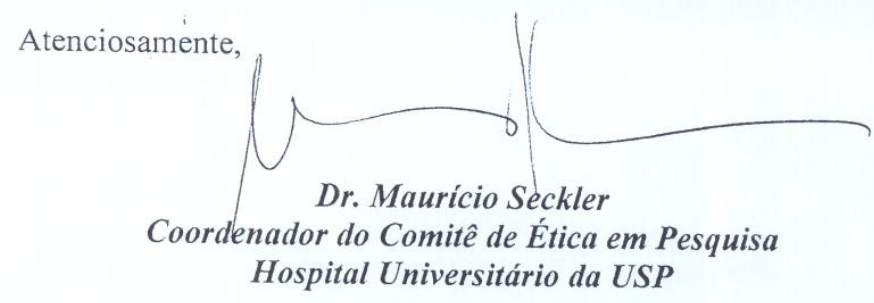


Dedico esse trabalho àquele que fez despertar o sentimento mais puro que pode existir, o amor de uma mãe para um filho.

Matheus você completou minha existência, você é o melhor presente de Deus para mim.

Te amo anjinho. 


\section{AGRADECIMENTOS}

Agradeço a Jesus em primeiro lugar, por tudo que já fez, e o que ainda virá:

"Eis por que nunca desanimamos. Embora os nossos corpos vão morrendo, a força interior que temos no Senhor vai crescendo dia a dia. Estes nossos sofrimentos e aflições, afinal de contas, são bem pequenos e não durarão muito tempo. Entretanto, este curto tempo de angústia resultará na mais rica benção de Deus sobre nós para todo sempre! Portanto, não olhamos para aquilo que podemos ver atualmente, as dificuldades que nos rodeiam, mas olhamos para frente, para as alegrias do céu que ainda não vimos. As aflições logo desaparecerão, mas as alegrias futuras durarão eternamente." - 2 Coríntios 4: 16-18.

À minha querida Orientadora, Chefa e Amiga: Professora Dra. Marília Cerqueira Leite Seelaender, obrigada pela paciência, por ter acreditado e confiado em mim, pela disposição e energia, e muito obrigada por ser uma amiga sempre presente nos principais momentos da minha vida nesses últimos anos.

À minha família: Pai e Mãe, muito obrigada por me apoiarem sempre, amo muito vocês dois. Apesar de muitas vezes ser um pouco rebelde, sou grata a tudo, vocês me ensinaram a ser uma pessoa melhor e sempre lutar pelo melhor, não importa quão grande seja a luta. Além de tudo, me ensinaram algo muito especial: a essência do amor. Aos meus irmãos queridos; Adriana e Alex: não imagino como teria sido minha infância sem vocês dois, não imagino como seria agora sem ter o apoio de vocês. Aos meus sobrinhos: Bruna, Gabriel e Luiz Felipe (Gato da Titia).

À Emília Ribeiro, que me ensinou muito durante esses anos no laboratório, com suas técnicas e os "pulos do gato", mas principalmente, me acolheu com seu amor e amizade. Minha eterna gratidão.

À amiga querida Renata Silvério (Rê), que compartilhou os momentos difíceis e alegres. Obrigada pelos ataques de riso e pela grande disposição para me ajudar.

Aos amigos Fábio Lira (Fio), José César Rosa Neto (Zeca) e Alex Shimura, que primeiro me acolheram no laboratório e sempre me ajudaram muito na bancada, muito do que aprendi eu devo a vocês, além disso, muito obrigada pela amizade.

Ao Miguel Luiz Batista Junior e Rodrigo Xavier, obrigada por toda colaboração e apoio. 
À Luana Levy, muitíssimo obrigada por sua ajuda.

Aos amigos do Laboratório de Lípides: Robson Eder, Daniela Caetano, Luiz Carnevalli Junior; aqueles que vieram um pouco depois: Felipe Donatto, Míreia Olivan, Juliana Penonne (Keith); aqueles que chegaram agora: Rodolfo Gonzalez, Henrique, Fernando Rosa, Adriana, Patrícia Rocha, Lucas, Felipe, Emídio.

A Profa Marinilce, muito obrigada por tudo, e ao pessoal do seu laboratório: Marcelo Lamers, Mara Rubia e a "nova geração"; Maíra, Ana Flávia, Mariana.

A Profa Alisson e o pessoal do laboratório: Marcel, Renata, Fernanda Seracchi e ao querido Prof. Bauer.

Ao Professor Emer pelas conversas e verdadeiros conselhos de amigo, e ao pessoal do seu laboratório.

Ao meu grande amigo: Luiz Fernando Domingos, não poderia me esquecer de você, isso seria imperdoável. Obrigada por me incentivar e não me deixar desistir. Isso merece uma grande cambalhota.

Ao Gaspar Ferreira de Lima e Edson Rocha de Oliveira pela maravilhosa assistência técnica na microscopia eletrônica.

Ao Dr. Paulo Alcântara e o Dr. Pinhattta, os médicos responsáveis por disponibilizarem a parceria formada entre o laboratório de lípides e o Hospital Universitário, muito obrigada, por todo suporte e auxílio durante os procedimentos cirúrgicos. A toda equipe de médicos e enfermeiros da Clinica Cirúrgica do Hospital Universitário que contribuíram para realização do trabalho.

A todos do Departamento de Biologia Celular e do Desenvolvimento, especialmente ao pessoal da secretária: Celiana, Ana Lúcia, Eloise pela imensa disposição e prontidão.

Ao pessoal da biblioteca, em especial a Monica pela grandiosa paciência e ajuda. 


\section{RESUMO}

ALVES, M. J. Efeito da caquexia associada ao câncer em componentes da matriz extracelular do tecido adiposo. 2011. 72 f. Dissertação (Mestrado em Biologia Celular e Tecidual) - Instituto de Ciências Biomédicas, Universidade de São Paulo, São Paulo, 2011.

A profunda perda de tecido adiposo é considerada um marcador na caquexia associada ao câncer. No entanto, as alterações pronunciadas pela caquexia sobre a matriz extracelular do tecido adiposo, ainda não estão elucidadas. O objetivo do estudo foi avaliar os efeitos da caquexia associada ao câncer em componentes da matriz extracelular do tecido adiposo subcutâneo de pacientes. Pacientes do Hospital Universitário (HU) foram divididos em dois grupos: portadores de tumor com caquexia (TC) e controles (C). Amostras de tecido adiposo subcutâneo foram analisadas quanto aos aspectos morfológicos (HE e Picro Sirius Red), ultraestruturais (microscopia eletrônica), morfométricos (área, diâmetro e perímetro do adipócito), moleculares por RT-PCR em tempo real para os genes: colágeno I (COL1A1), III (COL3A1), VI (COL6A1), fibronectina (FN1) e metaloproteinase 2 (MMP2) e por imunohistoquímica para colágeno (III, VI), fibronectina e metaloproteinase 2 (MMP2). O presente estudo relata alterações das características morfológicas dos adipócitos incidentes sobre área, diâmetro e perímetro dos adipócitos. A expressão gênica do COL6A1, FN1 estava aumentada no TC, que mostrou ainda redução na expressão da MMP2. A imunopositividade para colágeno $\mathrm{VI}$, colágeno III e fibronectina foi mais evidente no TC, e para MMP2 foi mais positiva em C. Conclusão: A caquexia associada ao câncer afeta profundamente o tecido adiposo conduzindo à fibrose tecidual.

Palavras-chave: Caquexia associada ao câncer. Tecido adiposo. Matriz extracelular. Fibrose. 


\section{ABSTRACT}

ALVES, M. J. Effects of cancer cachexia on the components of the adipose tissue extracellular matrix. 2011. 72 p. Masters thesis (Cellular and Tissue Biology) - Instituto de Ciências Biomédicas, Universidade de São Paulo, São Paulo, 2011.

Profound loss of adipose tissue is a hallmark of cancer cachexia. Nevertheless, the changes caused by cancer cachexia regarding the adipose tissue extracellular matrix have not yet been fully described. The aim of the study was to evaluate the effects of cancer cachexia upon extracellular matrix components of the subcutaneous adipose tissue of cancer patients. Patients of the Hospital University (HU) were divided into two groups: tumour cachexia (TC) and control (C). Subcutaneous adipose tissue samples were analysed for morphological aspects (HE and Picro Sirius Red) ultrastructural (electron microscopy), morphometric (area, diameter and circumference of adipocyte) molecular analyses by real time RT-PCR for gene COL3A1, COL1A1, COL6A1, FN1 and MMP2, immunohistochemistry for collagen (III, VI), fibronectin and metaloproteinase 2 (MMP2). This study shows modifications of the morphological characteristics of the adipocytes with reduction of area, diameter and circumference. The gene expression of COL6A1 and FN1 was increase in TC, while there was reduced gene expression for MMP2. The immunopositivity for collagen VI, III and fibronectin was most evident in TC, and for MMP2 was decrease in C. Conclusion: cancer cachexia affects deeply the adipose tissue, leading to the emergence of tissue fibrosis.

Keywords: Cancer cachexia. Adipose tissue. Extracellular matrix. Fibrosis. 


\section{LISTA DE ILUSTRAÇÕES}

Figura 1. Desenho Experimental.

Figura 2. Características Morfológicas do Tecido Adiposo Subcutâneo.................................42

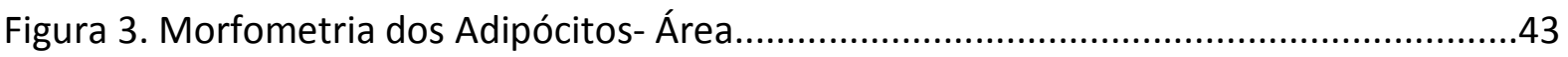

Figura 4. Morfometria dos Adipócitos- Diâmetro e Perímetro................................................43

Figura 5. Ultraestrutura do Tecido Adiposo Subcutâneo.........................................................44

Figura 6. Detecção de Colágeno com Coloração por Picro Sirius Red do Tecido Adiposo Subcutâneo .45

Figura 7. Expressão Gênica em Tempo Real do Gene COL1A1 ..............................................46

Figura 8. Expressão Gênica em Tempo Real do Gene COL3A1 ............................................47

Figura 9. Expressão Gênica em Tempo Real do Gene COL6A1 ...........................................47

Figura 10. Expressão Gênica em Tempo Real do Gene FN1 ....................................................48

Figura 11. Expressão Gênica em Tempo Real do Gene MMP2 ...........................................48

Figura 12. Imunohistoquímica para Colágeno III no Tecido Adiposo Subcutâneo.

Figura 13. Imunohistoquímica para Colágeno VI no Tecido Adiposo Subcutâneo

Figura 14. Imunohistoquímica para Fibronectina no Tecido Adiposo Subcutâneo .52

Figura 15. Imunohistoquímica para MMP2 no Tecido Adiposo Subcutâneo 


\section{LISTA DE TABELAS}

Tabela 1 - Sequências dos Primers para RT-PCR em Tempo Real.

.38

Tabela 2 - Características Cínicas Gerais, Antropométricas e Parâmetros

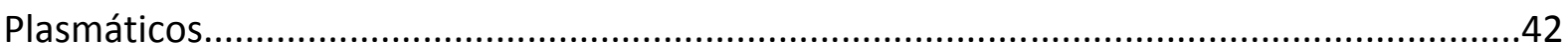




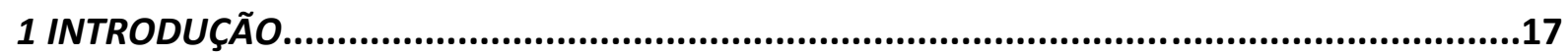

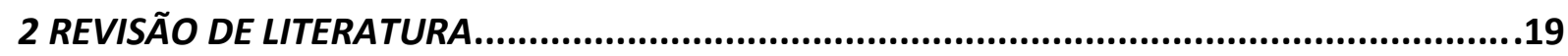

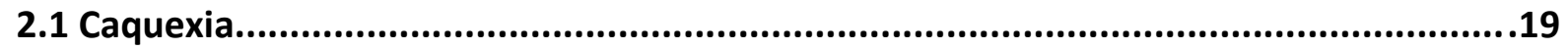

2.2 Tecido Adiposo e Caquexia Associada ao Câncer........................................................20

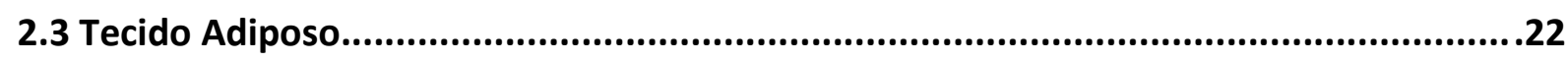

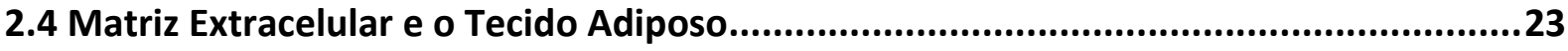

2.5 Alterações em Componentes Específicos da MEC .......................................................26

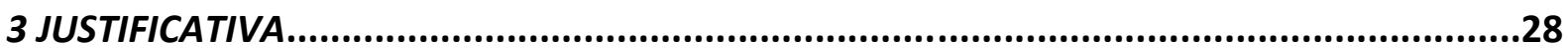

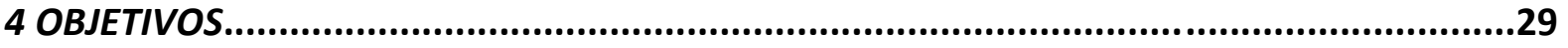

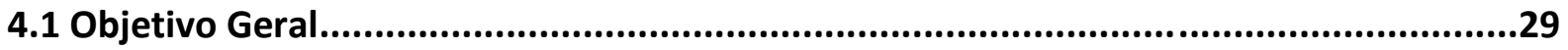

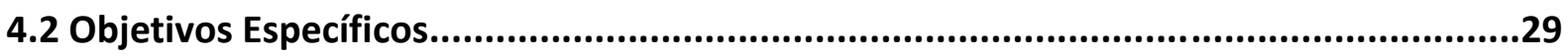

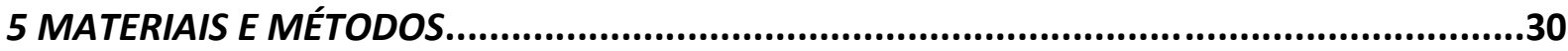

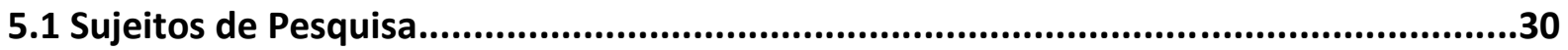

5.1.2 Critérios de Exclusão...............................................................................................31

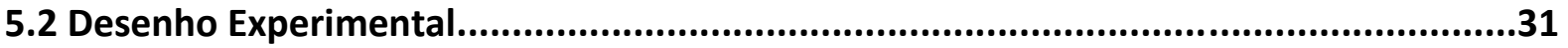

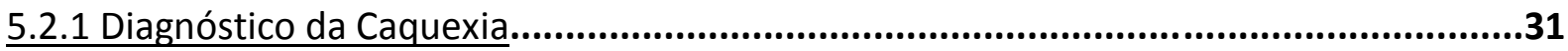

5.3 Procedimento Cirúrgico e Coleta do Tecido Adiposo Subcutâneo................................32

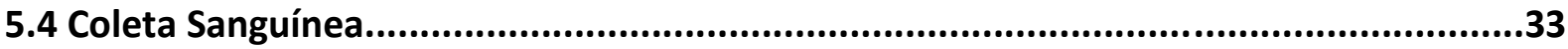

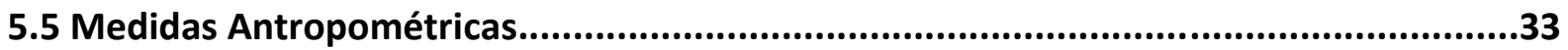

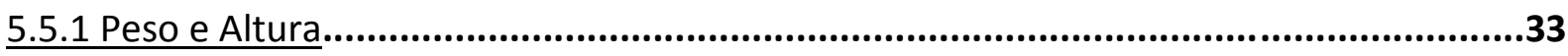

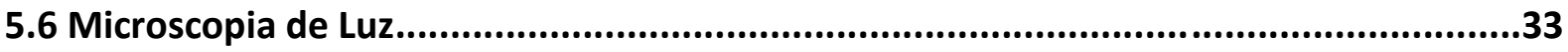




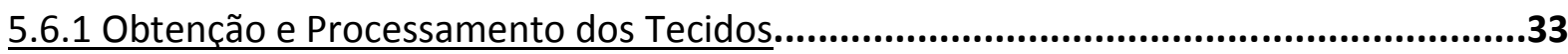

5.6.2 Desparafinização e Hidratação.....................................................................................34

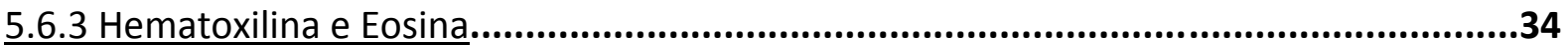

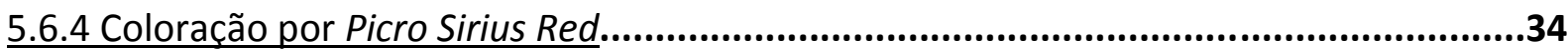

5.6.5 Reações de Imunohistoquímica.................................................................................35

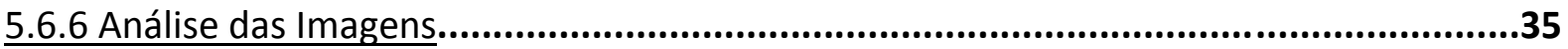

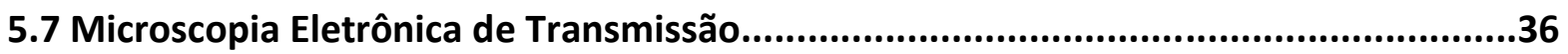

5.8 Quantificação da Expressão dos Genes COL1A1, COL 3A1, COL6A1, FN1, MMP2, 18s

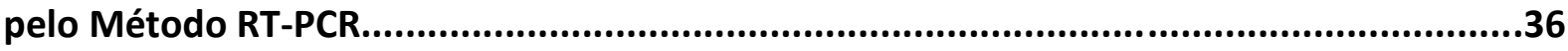

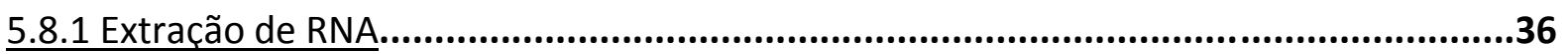

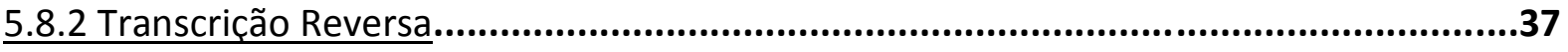

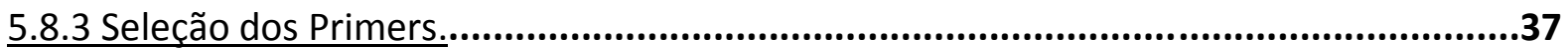

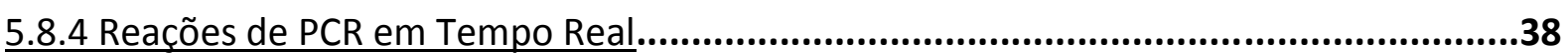

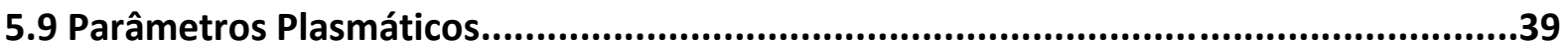

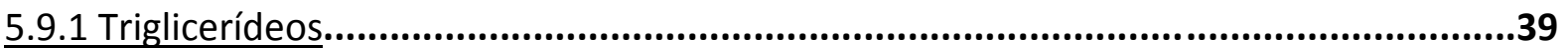

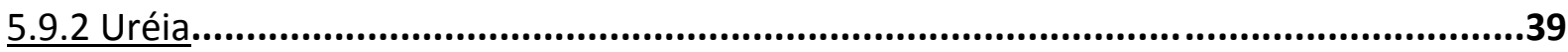

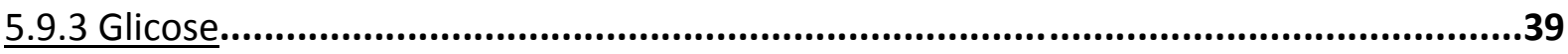

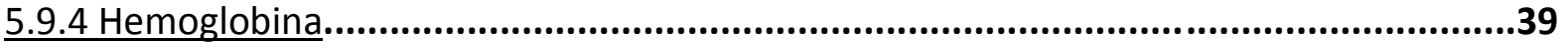

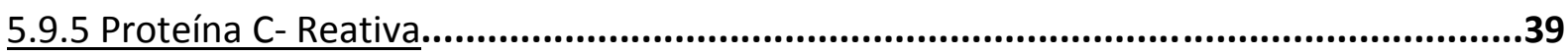

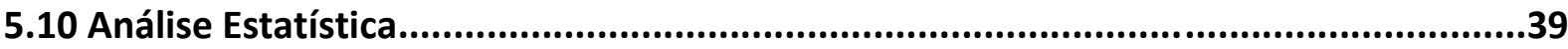

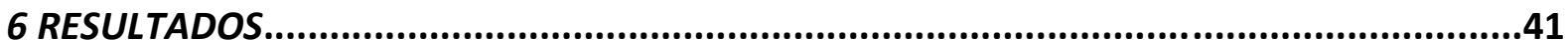

6.1 Características Clinicas Gerais, Antropométricas e Parâmetros Plasmáticos.................41

6.2 Aspectos Morfológicos e Morfométricos do Tecido Adiposo à Microscopia de

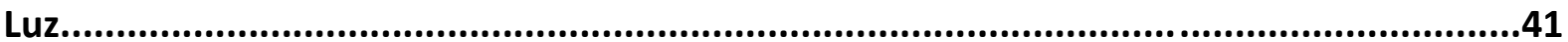

6.2.1 Aspectos Morfológicos do Tecido Adiposo...............................................................41

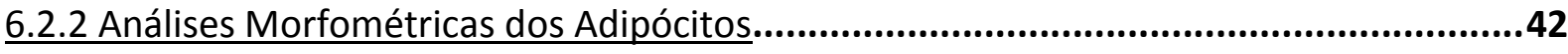

6.3 Aspectos Ultraestruturais do Tecido Adiposo Subcutâneo........................................44

6.4 Detecção de Colágeno com Coloração por Picro Sirius Red ........................................45

6.5 Expressão Gênica pelo Método RT-PCR em Tempo Real.............................................46

6.5.1 PCR em Tempo Real para o Gene COL1A1...................................................................46

6.5.2 PCR em Tempo Real para o Gene COL3A1...........................................................46

6.5.3 PCR em Tempo Real para o Gene COL6A1...............................................................47 


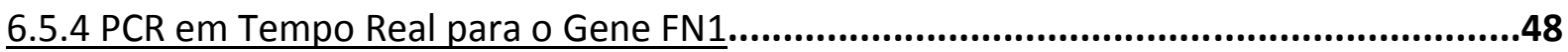

6.5.5 PCR em Tempo Real para o Gene MMP2....................................................................48

6.6 Imunohistoquímica para Colágeno tipo III..............................................................49

6.7 Imunohistoquímica para Colágeno tipo VI...........................................................50

6.8 Imunohistoquímica para Fibronectina.......................................................................52

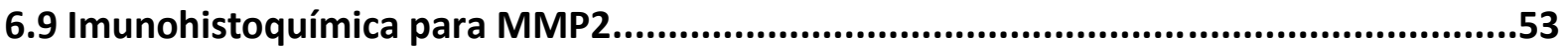

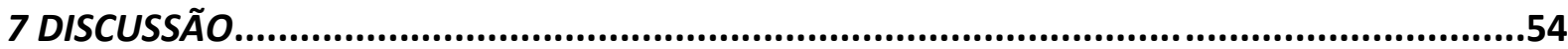

8 CONCLUSÃO

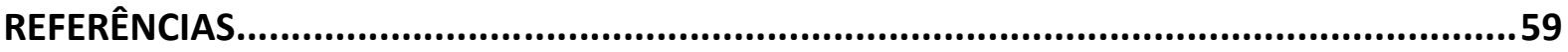

ANEXO A - Termo de Consentimento Livre e Esclarecido.................................................66

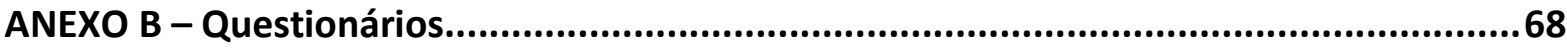




\section{INTRODUÇÃO}

A caquexia é a manifestação do avanço de doenças malignas, encontrada de maneira comum em pacientes com câncer avançado e na maior parte dos pacientes com câncer antes da morte (ARGILÉS, 2010). Uma vez estabelecida, a caquexia não pode ser revertida nos pacientes com câncer e, isso exalta sua própria importância.

A ideia característica da imagem do indivíduo caquético em um estado de má condição pode ser encontrada em descrições bíblicas por Rei Davi, datando mais de 3500 anos atrás (BEN-NOUN, 2004). A origem da palavra caquexia, no entanto, é grega, proveniente de relatos sobre doenças crônicas, sendo uma das primeiras descrições realizada por Hipócrates. Desde então, podemos encontrar na história muitas descrições sobre a caquexia que a caracterizam como uma síndrome que afeta múltiplos compartimentos e sistemas culminando no caos metabólico associado à perda de peso.

As emergentes visões da caquexia tanto como um processo inflamatório crônico, como uma desordem metabólica impressionante, demonstram que as informações obtidas até o presente momento são insuficientes para descrever a enorme complexidade acerca da síndrome. Houve um crescente interesse, nos últimos anos, em tentar expandir a compreensão das descrições para o âmbito clínico, a fim de propiciar melhor qualidade de vida ao paciente, bem como, a identificação prévia ao diagnóstico da síndrome e o desenvolvimento de possíveis tratamentos (EVANS et al., 2008).

Por si só, o câncer possui etiologia complexa e é uma causa de morte presente no mundo inteiro. A International Agency of Research in Cancer (2002) relata que aproximadamente $50 \%$ dos pacientes que são diagnosticados com câncer são curados, enquanto os outros $50 \%$ morrem. Cerca de $80 \%$ dos pacientes com câncer desenvolvem a caquexia, sendo a causa direta responsável pelo óbito entre $22 \%-40 \%$ desses pacientes (FOX et al., 2009).

A perda acentuada de tecido adiposo branco é um dos principais "marcadores" clínicos da caquexia associada ao câncer (BING et al., 2009). Antes, apenas visto como reservatório energético, a importância do tecido adiposo foi elucidada com a descoberta das adipocinas, em especial a leptina (ZHANG, 1994) atribuindo ao tecido adiposo à função de órgão endócrino. Fica claro então, que o tecido adiposo é de extrema importância na etiologia de diversas doenças, das quais a obesidade é a mais estudada. 
As células do tecido adiposo encontram-se embebidas por matriz extracelular. Nos últimos anos houve um incrível aumento da atenA matriz extracelular

Ao nosso conhecimento, não existem evidências até o presente momento relacionando componentes da matriz extracelular no tecido adiposo com a síndrome da caquexia associada ao câncer. Desta forma, é uma oportunidade ímpar investigar os efeitos da caquexia associada ao câncer em humanos nos componentes da matriz extracelular. 


\section{REVISÃO DE LITERATURA}

\subsection{Caquexia}

A palavra caquexia tem origem do termo grego "kakos hexis", que significa má condição (ARGILES et al., 2003). Sua manifestação tem sido bastante estudada no câncer, embora não seja a ele exclusiva, podendo estar associada a diversas outras doenças tais como: síndrome da imunodeficiência adquirida (AIDS), moléstias digestivas, doença crônica obstrutiva pulmonar, doenças cardíacas crônicas e, em estágios terminais de falência renal (ARGILÉS et al., 2010).

Hipócrates apud Katz e Katz (1962) descreveu há mais de 2000 anos a caquexia como uma condição na qual: a carne é consumida e se transforma em água, ... o abdômen enche de água, os pés e as pernas incham, os ombros, clavículas, tórax e coxas a derreter... a doença é fatal (460-370 BC).

De acordo com a revisão de Bennani-Baiti e Walsh (2009), por volta de 1915, para Howard Canning Taylor, o fundador da Sociedade Americana para o Controle de Câncer, a caquexia era como uma manisfestação tardia de um processo maligno em que a figura clínica é bastante característica do câncer. Em 1997 foi proposta, por Roubenoff et al., a diferença entre caquexia e simples perda de peso, sugerindo que o termo caquexia seja usado somente para involuntária perda de peso.

Apesar dos primeiros relatos sobre a caquexia datarem a séculos atrás, e de notável o crescente interesse das pesquisas sobre a mesma, somente no ano de 2000 é que houve a $1^{\text {a }}$ Conferência da Caquexia, e ainda em 2005, sua definição era um dos principais tópicos. Devido à enorme complexidade e caráter multifatorial, a caquexia não é facilmente definida, muitos autores a consideravam uma síndrome metabólica caracterizada pela progressiva diminuição do peso corporal, com depleção no tecido adiposo e no músculo esquelético (ARGILÉS et al., 2010; BRUERA; SWEENNEY, 2000; LAVIANO et al., 2004; TISDALE, 2002).

Contudo, em 2011, a revisão de Fearon et al. apresenta como um consenso internacional a definição da caquexia associada ao câncer: síndrome multifatorial, na qual há perda contínua de massa muscular (com perda ou ausência de perda de massa gorda), que não pode ser totalmente revertida pela terapia nutricional convencional, conduzindo ao comprometimento funcional progressivo do organismo. 
Além disso, anorexia, inflamação, resistência à insulina, distúrbios metabólicos, astenia, aumento da quebra e diminuição da síntese proteica são clinicamente observadas com frequência na síndrome (ARGILÉS et al., 2010; EVANS et al., 2008).

A caquexia associada ao câncer ocorre na maior parte em pacientes em estágios terminais, acometendo cerca de 65\% destes pacientes (LAVIANO et al., 2005). A incidência de perda de peso pode variar de acordo com a localização e o tipo de tumor. Em pacientes com tumores de mama, formas menos agressivas de linfomas do tipo Hodgkin's e leucemias não linfocíticas, a incidência de perda de peso é entre $10-40 \%$. Os tumores no pulmão, na próstata, as formas mais agressivas de linfomas não Hodgkin's e no câncer de cólon estão associados frequência de perda de peso entre 50 a 65\%. Já nos pacientes com câncer pancreático ou gástrico, esta é superior a 80\% (LAVIANO et al., 2005).

A perda de peso é um importante indicador para pacientes com câncer, a qual está relacionada diretamente com o tempo de sobrevivência do paciente. Pacientes com perda de peso superior a $15 \%$ já demonstram perda das funções fisiológicas, sendo que a morte ocorre quando a perda de peso se aproxima de $30 \%$. Portanto, a caquexia não somente afeta a qualidade de vida do paciente, mas também está associada com o aumento de morbidade e mortalidade (TISDALE, 2002). Adicionalmente, a caquexia compromete exacerbadamente os tratamentos de quimioterapia e radioterapia nos pacientes com câncer (TISDALE, 2002).

As terapias nutricionais têm falhado no intuito de reverter os efeitos da caquexia. Especula-se hoje, que as diferentes combinações entre os tratamentos vigentes podem ter efeitos benéficos e prolongar o tempo de sobrevivência do paciente (ARGILÉS et al., 2010). No entanto, as opções de tratamento para caquexia, ainda são limitadas. Por exemplo, a total nutrição parenteral parece estabilizar o peso, porém não impede que o paciente continue a perder massa muscular esquelética ou corrija as anormalidades metabólicas. Tentativas com medicação anti-inflamatória, também não têm sido promissoras, e a combinação com potenciais agentes farmacológicos incluindo agentes orexígenos, também são carentes de comprovação de eficácia efetiva (EVANS et al., 2008).

\subsection{Tecido Adiposo na Caquexia Associada ao Câncer}


Apesar do atual consenso sobre a definição da caquexia, e de estudos recentes apontarem a perda de massa muscular como mais importante para a patologia e o diagnóstico da síndrome (EVANS et al., 2009; FEARON et al., 2011), muito se especula sobre o tecido adiposo e seu verdadeiro papel na caquexia.

A profunda perda do tecido adiposo na caquexia associada ao câncer, no entanto, é apontada por Bing e Trayhurn (2009), como um efetivo marcador da caquexia, e este sintoma precede a perda de massa muscular, podendo inclusive ser utilizada como marcador diagnóstico.

Murphy et al. (2010) relatam que a extensiva perda de tecido adiposo é a chave característica da caquexia associada ao câncer. No estudo, pacientes com câncer no trato gastrointestinal, cólon-retal, rim e próstata apresentaram acelerada perda dos depósitos de tecido adiposo, sete meses anteriores à morte, e perda de aproximadamente $29 \%$ do total de tecido adiposo dois meses antes do óbito.

Em outro elegante estudo, realizado por Dahlman et al. (2010), a caquexia associa-se preferencialmente à diminuição do tecido adiposo dos pacientes de câncer, enquanto, a massa muscular não é afetada. Pouco se sabe a respeito dos mecanismos envolvidos na perda do tecido adiposo, porém, os autores a atribuem à diminuição no conteúdo lipídico do adipócito, em conjunto com as mudanças na expressão de genes que regulam o turnover energético, citoesqueleto e matriz extracelular.

O turnover energético está relacionado com a concentração plasmática de glicerol, um indicativo da lipólise decorrente do tecido adiposo periférico. Sabemos que na vigência da caquexia, de acordo com Argilés (2003), a razão entre o aumento da atividade lipolítica com diminuição na atividade enzimática da lipase de lipoproteína (LPL) e a diminuição da lipogênese resulta na diminuição de esterificação e deposição lipídica, além disso, como consequência da diminuição da LPL há a hipertrigliceridemia e aumento nos níveis de colesterol (SEELAENDER, 1996).

Em relação ao conteúdo lipídico do adipócito, e de relevância para o tecido adiposo, já foram descritas importantes modificações pelo nosso grupo de pesquisa. Primeiramente, Bertevello e Seelaender (2001) demonstraram o aumento na área, perímetro e eixos maior e menor dos adipócitos dos depósitos; mesentérico, retroperitoneal e epididimal de animais portadores de tumor (carcinosarcoma de Walker 256) comparados com o grupo controle. Também, foram encontradas alterações nos aspectos da ultraestrutura dos adipócitos dos 
depósitos retroperitoneal e epididimal, incidindo sobre a morfologia da membrana plasmática e a presença de corpos nucleares.

O trabalho de Machado, Costa Rosa e Seelaender (2004), descrevem os aspectos nos adipócitos, nos três principais depósitos de tecido adiposo (retroperitoneal, epididimal e mesentérico) de ratos caquéticos, relatando a presença de espaços interadipócitos dilatados e ocupados por células infiltrantes. Essas células foram identificadas por reação de imunohistoquímica como macrófagos, enquanto a análise ultraestrutural demonstrou evidências da presença de diferentes macrófagos residentes do tecido, apresentando um grande número de inclusões lipídicas em seu citoplasma.

Bing et al. (2006) publicaram no British Journal of Cancer um trabalho com tema "Atrofia adiposa na caquexia associada ao câncer". Foram utilizados camundongos portadores do tumor MAC16 que induz a caquexia. As análises morfológicas após 18 dias da inoculação do tumor demonstraram alterações no tecido adiposo epididimal desses animais em relação ao controle, além de espaço interadipócito dilatado, corroborando os resultados obtidos pelo nosso grupo. Essas áreas, denominadas pelos autores de lipoatróficas possuíam muitos adipócitos de formato irregulares e intensa marcação no espaço extracelular mostrando o aumento no conteúdo de colágeno e, portanto, da matriz extracelular do tecido adiposo.

\subsection{Tecido Adiposo}

O tecido adiposo é constituído por outros tipos celulares além dos adipócitos, tais como; pré-adipócitos, fração estromal vascular, células endoteliais, fibroblastos, macrófagos e matriz extracelular e ainda, é altamente inervado (FLIERS et al., 2003; TRAYHURN; BEATTIE, 2001). O adipócito é considerado uma célula ímpar, pois a gotícula lipídica ocupa cerca de 85-90\% do seu corpo celular total, empurrando o núcleo e uma fina camada de citosol para periferia da célula (FONSECA-ALANIZ et al., 2007). A capacidade de armazenamento do triacilglicerol pelo adipócito é surpreendente, de fato que as células possuem o tamanho médio de 90 a $100 \mu \mathrm{m}$ de diâmetro (FONSECA-ALANIZ et al., 2007).

Somando-se a clássica função de reservatório energético, sabe-se hoje, que o tecido adiposo é reconhecido como importante órgão endócrino ativo, e que as células adiposas se 
mostram especializadas e responsáveis por secretar moléculas sinalizadoras integrando a comunicação com outros órgãos e tecidos (POND, 2003; WANG et al., 2008 ).

A mudança de compreensão quanto ao papel do tecido adiposo se deu com a identificação da leptina em 1994 (ZHANG et al., 1994), que o levou a ser caracterizado por sua função endócrina. Em 1996, Smith intitulou o tecido adiposo como "órgão endócrino" fundamentado na função da leptina (SMITH, 1996). A literatura traz um crescente número desses fatores secretados exclusivamente pelos adipócitos, denominados então, de adipocitocinas, ou adipocinas, apontando o papel do tecido adiposo na modulação de cascatas de sinalização em tecidos-alvos e na regulação da homeostase energética, tornando-o um órgão com funções endócrinas, parácrinas e autócrinas. Na obesidade, ou na síndrome metabólica, por exemplo, os indivíduos apresentam um característico desbalanço no perfil das adipocinas (DENG; SCHERER, 2010; HALBERG et al., 2008).

Além das adipocinas, os adipócitos são reconhecidos por secretarem outros fatores como: citocinas, fatores pró- angiogênicos e pró-mitogênicos e diversos componentes da matriz extracelular (DENG; SCHERER, 2010).

\subsection{Componentes da Matriz Extracelular e o Tecido Adiposo}

A matriz extracelular (MEC) é um complexo de proteínas e polissacarídeos e o balanço entre cada molécula da matriz denota características específicas para cada tecido. $\mathrm{A}$ composição da MEC afeta o controle celular na proliferação, na migração, na diferenciação e no desenvolvimento do tecido, sendo que o tecido adiposo não é uma exceção (NAKAJIMA et al., 1998).

O primeiro relato acerca da estrutura da MEC no tecido adiposo foi realizado por Napolitano et al. ( 1963) que observou à microscopia eletrônica, o tecido adiposo branco de ratos e as células adiposas encontravam-se embebidas em um sistema de fibras de colágeno. Anos depois, estudos realizados com técnicas imunohistoquímicas verificaram que cada adipócito é envolvido por uma membrana basal composta de colágenos e outras proteínas da matriz (PIERLEONI et al., 1998).

Durante o desenvolvimento do tecido, na diferenciação de pré-adipócitos a adipócitos, as modificações na morfologia celular são acompanhadas por mudanças na expressão de diversas proteínas da MEC (HALBERG et al., 2008). Em diferenciados pré- 
adipócitos intramusculares bovinos, Nakajima et al. (1998), demonstraram a presença dos colágenos tipos I, II, III, IV, V e VI, laminina, e fibronectina, sendo que o colágeno tipo II tem menor abundância comparado aos outros.

Kubo et al. (2000) realizaram um trabalho com células do tecido adiposo subcutâneo de camundongos observadas em três diferentes estágios de diferenciação. Os colágenos dos tipos III, V, VI foram detectados desde o primeiro estágio, e ainda, após a plena diferenciação das células, enquanto que, o colágeno tipo I estava totalmente organizado somente no estágio tardio, formando um sistema fibrilar e conectando os adipócitos maduros. Já em relação à fibronectina, os autores relatam que foi a primeira a estar expressa entre os outros componentes no início da diferenciação, e também, a primeira a ser degradada com o processo, apontando que essa diminuição da fibronectina é prérequisito entre os componentes da MEC para a diferenciação do tecido, além de contribuir com a organização dos colágenos no início do processo.

A fibronectina é uma glicoproteína adesiva abundantemente presente na matriz fibrilar dos tecidos. A formação de suas fibrilas é um processo mediado pelas células e essencial para a vida, suas fibrilas se distribuem em ramificações em volta das células, conectando-as às células vizinhas. Estruturalmente, a fibronectina é formada por duas cadeias polipeptídicas, unidas por um par de pontes dissulfeto de cada sub-unidade Cterminal. Seus domínios são capazes de interagir com outras moléculas da matriz, receptores de superfície celular, glicosaminoglicanas e outras moléculas de fibronectina (SINGH et al., 2010).

A família de proteínas colágenas é a mais abundante das proteínas componentes da MEC (aproximadamente 30\% da massa proteica do corpo humano), possuem características que contribuem para a ancoragem e arcabouço celular, estabilidade de órgãos e tecidos e manutenção da integridade estrutural (GELSE et al., 2003; MYLLYHARJU; KIVIRIKKO, 2004). Todos os colágenos tem em comum a molécula formada por tripla hélice de cadeias polipeptídicas, denominadas $\alpha$ cadeia contendo domínios com repetições das sequências Gly-X-Y de aminoácidos. A presença do aminoácido glicina é essencial, e geralmente, a prolina é encontrada na posição $X$, e a hidroxiprolina na posição $Y$ fornecendo estabilidade para a molécula (MYLLYHARJU; KIVIRIKKO, 2004).

Os colágenos do tipo I e III são conhecidos como colágenos fibrilares por apresentarem a propriedade de se agregarem em fibrilas organizadas. São sintetizados como 
percussores, pró-colágenos, e então, após a remoção proteolítica de seus pró-peptídeos no $\mathrm{N}$ - e C-terminal no espaço extracelular, se tornam moléculas funcionais e ativas (RICARDBLUM; RUGGIERO, 2005). O colágeno do tipo VI é considerado microfibrilar sendo altamente rico em pontes dissulfídicas que contribuem para formação de uma rede de filamentos entrelaçados com outros fibras colágenas (GELSE et al., 2003). Este é composto por três cadeias $\alpha 1, \alpha 2, \alpha 3$ formando intracelulares heterotrímeros que subsequentemente formam complexos de tetrâmeros de trímeros antes de ser secretados.

No tecido adiposo de humanos, já foram descritas 20 sub-unidades de 12 diferentes tipos de colágenos, porém, não foi detectada a presença dos tipos II, XI e XXIII (MARIMAN; WANG, 2010). Além disso, o colágeno tipo VI é abundantemente produzido e secretado pelos adipócitos. Esse tipo contribui para as funções essenciais da MEC, providencia suporte estrutural para as células e está envolvido no aumento de fatores de crescimento, citocinas e outros ligantes na superfície celular e ainda, por si só assume importantes efeitos de sinalização. Em adição às proteínas colágenas, a fibronectina é frequentemente observada no tecido adiposo e, parece ser essencial à regulação da arquitetura tecidual e à diferenciação de adipócitos (DIVOUX; CLEMENT, 2011).

O maior grupo de enzimas presentes na MEC é o das metaloproteinases da matriz (MMPs), que realizam a regulação da composição célula- matriz e são responsáveis por hidrolisarem uma variedade de componentes da MEC. (CHAKRABORTI et al., 2003). Em adição a função de clivagem, as MMPs, por exemplo, criam espaços durante a migração celular, regulam a arquitetura tecidual e ainda, são capazes de ativar, desativar, ou modificar a atividade de moléculas sinalizadoras (PAGE-MCCAW; EWALD; WERB, 2007).

As MMPs são endopeptidases (possuem como substrato as ligações peptídicas internas) zinco dependentes. Todos os membros da família das MMPs contêm em sua estrutura, um pró-peptídeo e um domínio catalítico, no qual está incluso o sítio ligante de zinco e íons adicionais de cálcio e zinco que mantêm a estabilidade da molécula, além de um sítio ativo de metionina altamente conservado (CHAKRABORTI et al., 2003).

A gelatinase $A(M M P 2)$ também conhecida por seu peso molecular de $72 \mathrm{kDa}$, possui na posição C-terminal um domínio homólogo à hemopexina entre o sítio ligante de zinco, que atua na interação da enzima com seu substrato (CHAKRABORTI et al., 2003). A distribuição tecidual dessa endopeptidase pode variar muito, sendo encontrada 
constitutivamente em muitas células enquanto em outras, é encontrada quando há estímulo.

Bouloumié et al. (2001) demonstram que o tecido adiposo subcutâneo de humanos é capaz de produzir e secretar a MMP2, e sua expressão é aumentada durante a diferenciação dos adipócitos, quando inibida resulta na falta de habilidade da célula em se diferenciar. $\mathrm{O}$ autor sugere que as MMPs podem ser importantes reguladores na diferenciação representando marcadores para inibição do crescimento do tecido adiposo.

Portanto, no tecido adiposo a MEC é crucial para manutenção da integridade estrutural dos adipócitos e além de importantes funções na adipogênese (DIVOUX; CLÉMENT, 2011). No entanto, a MEC do tecido adiposo tem recebido limitada atenção, apesar de evidências sugerindo que é funcionalmente importante para o adipócito (MARIMAN; WANG, 2010).

\subsection{Alterações em Componentes Específicos da MEC}

Diferentemente do que é observado na síndrome da caquexia, caracterizada por marcada perda de peso, a obesidade é uma síndrome metabólica onde há o ganho de peso com aumento de massa gorda (WANG et al., 2008). No desenvolvimento da obesidade, os pré-adipócitos se diferenciam a adipócitos e os adipócitos maduros armazenam maior quantidade de triglicerídeos alterando o volume e o tamanho celular. A hipertrofia dos adipócitos depende de mudanças na arquitetura tecidual e a MEC necessita de um processo de remodelamento para acomodar o crescimento dos adipócitos.

Khan et al. (2009) demonstraram, em um trabalho muito elegante, mudanças nos componentes da MEC, em diferentes condições de estresse metabólico que culminam em fibrose do tecido adiposo. Além disso, o estudo detectou um perfil de expressão gênica bastante alterada, com análise de microarray de colágenos do tipo I até VI no tecido adiposo. No estudo, os autores utilizaram animais modificados (sem expressão ou síntese do colágeno $\mathrm{VI}$ ), o que resultou em perda de densidade e perda de estrutura celular dos adipócitos.

No trabalho de Henegar et al. (2008) foram analisados perfis moleculares, além do mapeamento das interações no tecido adiposo subcutâneo em indivíduos obesos, e a 
obesidade resultou no aumento da regulação de genes relacionados com componentes da MEC.

Em outros tecidos tais como: fígado, pâncreas, rim e pulmão, durante o remodelamento tecidual, com a formação de tecido conjuntivo e o acúmulo da fibrose, há o rompimento de processos celulares contribuindo para má funcionalidade do órgão (DIVOUX; CLÉMENT, 2011).

Em relação ao papel das MMPs, este não está restrito aos processos de desenvolvimento, a literatura começa a demonstrar evidências que as MMPs também estão relacionadas com a presença de inflamação podendo ser pró-inflamatórias e antiinflamatórias. 


\section{JUSTIFICATIVA}

Durante o remodelamento tecidual ocorrem alterações no balanço entre os componentes da MEC frente à demanda imposta pelas células, que em situações patológicas está associada ao comprometimento da organização e função do tecido. Diante dessas evidências, alterações na composição da MEC podem levar à perda de plasticidade do tecido adiposo e culminar em fibrose. Contudo, nosso conhecimento ainda é restrito acerca do papel que a MEC desempenha no tecido adiposo em condições saudáveis, e ainda menos profundo em condições patológicas, os poucos estudos na literatura que tangem esse tema, restringem-se em sua quase totalidade à obesidade. Dessa forma, muito pouco se sabe sobre a MEC do tecido adiposo na caquexia associada ao câncer em humanos, e de qual será o impacto da regulação dos seus fatores sobre a estrutura e funções desse tecido.

Assim, pareceu-nos oportuno investigar os efeitos da caquexia associada ao câncer na regulação de fatores presentes na matriz extracelular. 


\section{OBJETIVOS}

\subsection{Objetivo Geral}

Diante a todas as alterações encontradas no tecido adiposo branco de ratos caquéticos portadores de tumor e, com vista na importância do tecido adiposo para síndrome decidimos avaliar os efeitos da caquexia associada ao câncer na matriz extracelular do tecido adiposo de pacientes portadores de tumores gastrointestinais.

\subsection{Objetivos Específicos}

1. Investigar os efeitos da caquexia associada ao câncer nos aspectos morfológicos e ultraestruturais do tecido adiposo subcutâneo de pacientes com câncer gastrointestinal.

2. Investigar os efeitos da caquexia associada ao câncer sobre a expressão dos colágenos I, III, VI, da fibronectina e MMP2 do tecido adiposo subcutâneo de pacientes com tumores gastrointestinais comparando ao tecido de indivíduos não caquéticos. 


\section{MATERIAIS E MÉTODOS}

\subsection{Sujeitos de Pesquisa}

Todos os sujeitos participantes da pesquisa foram voluntários e recrutados após a consulta, realizada no ambulatório do Hospital Universitário (HU) da Universidade de São Paulo (USP), por médicos especialistas da Clínica Médica Cirúrgica do hospital. Para inclusão do sujeito na pesquisa, foram usados os seguintes critérios;

- Homens ou mulheres, com idade entre 18- 100 anos (sem distinção de raça ou classe social pelo pesquisador);

Pacientes com diagnóstico de câncer e com proposta cirúrgica para tratamento de tumores gastro-intestinais, sendo que, a cirurgia deveria anteceder ao tratamento, tanto de quimioterapia ou radioterapia, ou qualquer outro tipo de tratamento. Esses pacientes deveriam também ser portadores de caquexia (descrito no item 5.2.1);

- Pacientes com indicação cirúrgica para o tratamento de hérnia inguinal, epigástrica, umbilical ou incisional, colecistite crônica calculosa (fora da fase aguda), ou diverticulite (fora de fase aguda).

Os diagnósticos foram realizados por exames clínicos, laboratoriais, endoscópicos ou de imagem, solicitados de acordo com a necessidade pelo médico responsável pelo paciente.

Todos os procedimentos realizados foram aprovados previamente pelo Comitê de Ética Humana do Instituto de Ciências Biomédicas/USP [788], em acordo com o Comitê de Ética Humana do Hospital Universitário/ USP [752/07].

As amostras somente foram coletadas, após a obtenção do termo de consentimento assinado pelo sujeito participante (Anexo A), e, todo material coletado foi usado exclusivamente para o propósito da pesquisa. Além disso, para que o sujeito participasse da pesquisa, esta não poderia modificar, ou mesmo, influenciar o tratamento terapêutico do paciente, modificar o contexto do procedimento cirúrgico ou anestésico, ou ainda, causar algum tipo de dor física ou constrangimentos para o paciente.

Todos os sujeitos portadores de câncer foram submetidos à cirurgia indicada pelo profissional que realizou o procedimento de acordo com o termo de consentimento informado em vigência no Hospital Universitário da USP. 


\section{$\underline{5.1 .2}$ Critérios de Exclusão}

Os pacientes que apresentaram na primeira consulta, ou mesmo depois desta, diagnóstico de: AIDS, falência renal, desordens autoimunes e doenças inflamatórias do intestino (tais como RCUI - retocolite ulcerativa inespecífica ou outras) foram exclusos da pesquisa.

\subsection{Desenho Experimental}

Os sujeitos que atenderam aos critérios de inclusão da pesquisa foram separados da seguinte forma:

- Grupo Tumor com Caquexia (TC) e Grupo Controle (C);
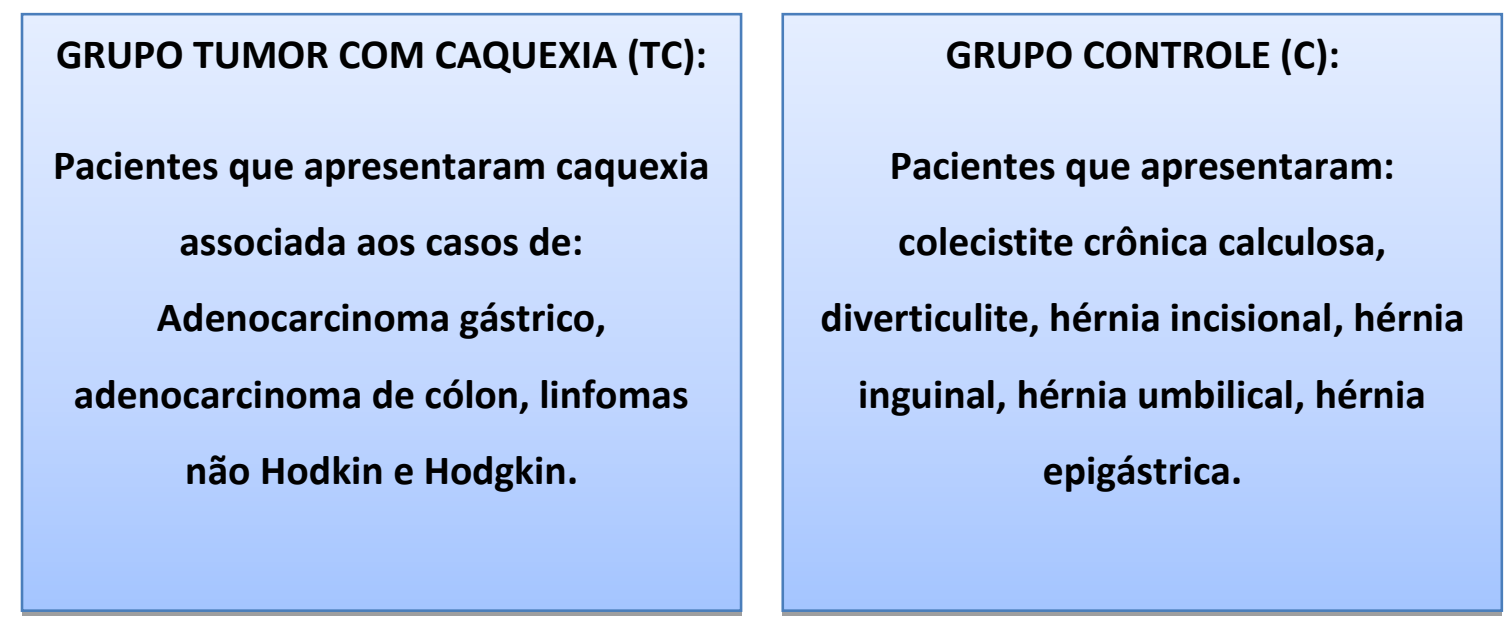

Figura 1. Desenho Experimental

\subsubsection{Diagnóstico da Caquexia}

Para inclusão do sujeito no grupo tumor com caquexia, os pacientes portadores de tumor gastrointestinal, também deveriam ser diagnosticados com caquexia. Para isso, os critérios estabelecidos para o diagnóstico da caquexia foram aqueles propostos por Morley et al. (2006):

-Mudança no peso corporal. Redução involuntária de peso corporal nos últimos 6 meses: $\geq 5 \%$ do peso inicial corporal. 
-Índice de Massa Corporal (IMC): Menor que $20 \mathrm{~kg} \cdot \mathrm{m}^{-2}$ para pacientes com idade inferior a 65 anos, e menor que $22 \mathrm{~kg} \cdot \mathrm{m}^{-2}$ para pacientes com idade superior ou igual a 65 anos. O IMC é determinado pela fórmula: IMC= peso corporal total $(\mathrm{kg}) /$ altura $^{2}(\mathrm{~m})$.

-Evidência de inflamação. Concentrações plasmáticas alteradas dos marcadores de inflamação (proteína C reativa).

Todos os pacientes foram considerados caquéticos quando apresentaram dois, ou mais dos critérios acima descritos.

\subsection{Procedimento Cirúrgico e Coleta do Tecido Adiposo Subcutâneo}

Como descrito no item 5.1, a coleta do tecido adiposo subcutâneo não trouxe nenhuma modificação para os procedimentos cirúrgicos realizados.

Para realização do procedimento, o sujeito se manteve deitado em uma maca, com monitoração cardíaca e arterial. Cada paciente realizou banho com sabão antisséptico, e recebeu uma limpeza na área do procedimento cirúrgico, a qual foi tricotomizada (remoção dos pelos) com uso de lâminas descartáveis. A anestesia foi aplicada de forma geral ou peridural, sempre de acordo com o médico anestesista responsável e individualizada para cada caso. Antes do procedimento cirúrgico, os pacientes foram submetidos à colocação de sonda ou catéteres, quando necessário, e a nova antissepsia com substância degermante de base alcoólica com colocação de campos cirúrgicos estéreis.

Entre os procedimentos cirúrgicos realizados estavam desde a vídeolaparoscopia ou laparotomia convencional nos casos das hérnias e colecistites, ressecção segmentar nos casos dos tumores de cólon, e gastrectomias parciais ou totais para os casos de tumores gástricos. A incisão na pele foi realizada com lâmina de bisturi esterilizada, individual e descartável e, a retirada do tecido adiposo subcutâneo foi realizada com uso de pinça e lâmina cirúrgicas, pelo médico responsável pelo procedimento cirúrgico. O tecido adiposo subcutâneo não foi classificado de acordo com a posição anatômica, sendo coletados tanto do tipo lamelar quanto areolar, contudo sempre na mesma topografia, superior ao umbigo, e nunca adjacente ao tumor, no caso do grupo TC.

O tecido coletado foi imediatamente dividido em alíquotas com o auxílio de lâmina e pinça cirúrgicas esterilizadas, individualizadas e descartáveis colocados sobre bandeja cirúrgica estéril. Cerca de $100 \mathrm{mg}$ foram divididos e colocados em paraformaldeído 4\% e 
glutaraldeído 3\% para as análises histológicas. Aproximadamente $500 \mathrm{mg}$ foram colocados no TRIzol ${ }^{\circledR}$ Reagent para as análises moleculares e o restante foi colocado em Criovials específicos e imediatamente congelados, e esses foram armazenados no freezer $-80^{\circ} \mathrm{C}$ para posteriores análises.

\subsection{Coleta Sanguínea}

As coletas sanguíneas foram realizadas durante os procedimentos cirúrgicos. Aproximadamente $10 \mathrm{ml}$ de sangue foram coletados no acesso venoso usado para o procedimento de anestesia. As amostras coletadas foram centrifugadas (Hettich Zentrifugen, Alemanha) a 3000 rotações por minuto durante 15 minutos à $4{ }^{\circ} \mathrm{C}$. O soro e o plasma foram separados, colocados em eppendorfs e então, armazenados no $-80{ }^{\circ} \mathrm{C}$ para posteriores análises.

\subsection{Medidas Antropométricas}

\section{$\underline{5.5 .1}$ Peso e Altura}

Os sujeitos participantes foram pesados com balança digital na entrevista inicial no ambulatório e na véspera do procedimento cirúrgico. A altura foi determinada na posição em pé, com auxílio de um estadiômetro. Essas medidas foram utilizadas para determinar o índice de massa corporal (IMC), calculado por;

$I M C=$ Peso $(\mathrm{kg}) /$ Altura $^{2}(\mathrm{~m})$.

\subsection{Microscopia de Luz}

\subsubsection{Obtenção e Processamento dos Tecidos}

Durante a cirurgia, os fragmentos obtidos foram colocados em solução fixadora de paraformaldeído $4 \%(\mathrm{p} / \mathrm{v})$ em tampão fosfato, $\mathrm{pH} 7.4$, a qual, circulou nos fragmentos cúbicos de aproximadamente $1 \mathrm{~cm}^{3}$, e permaneceram submersos por 24 horas, após, os fragmentos eram passados para o álcool $70 \%$ em que podiam ser armazenados por tempo 
maior. Os fragmentos quando submetidos ao processamento, eram primeiramente desidratados com concentração crescente de álcool, diafinizados com banhos de xilol e incluídos em paraplast (Paraplast X-TRA, SIGMA-ALDRICH). Após a inclusão, os fragmentos foram colocados em "Tissue Cassetes" (FISCHER SCIENTIFIC) e cortados no micrótomo rotatório ( $R$ Jung-Heidelberg). Os cortes de $5 \mathrm{~m}$ foram estendidos sobre lâminas, previamente limpas em água e cobertas com porilisina (SIGMA).

\subsubsection{Desparafinização e Hidratação}

Os cortes foram desparafinizados com banhos de xilol (3 banhos de 30 minutos cada), e hidratados com álcool em concentrações decrescentes ( 2 × 100\%, 10 minutos; 1 ×95\%, 10 minutos; 1 x 70\% por 10 minutos) e lavados com água destilada.

\section{$\underline{5.6 .3 \text { Coloração por Hematoxilina e Eosina }}$}

Após o material ter sido desparafinizado e hidratado foi corado por aproximadamente a 1 minuto com corante hematoxilina, seguido de lavagens com água destilada por 5 minutos, e 45 segundos no corante eosina. Os cortes passaram rapidamente pelo álcool absoluto, e então, permaneceram por 5 minutos nos álcoois 95\%, 70\%, respectivamente, e por último, receberam banhos com xilol ( 3 × 5 minutos). $E$ as lâminas foram fechadas com Permount (Tuluene Solution, Fischer Scientific).

\subsubsection{Coloração por Picro Sirius Red}

Após a desparafinização e hidratação, o material foi corado com Direct Red 80 (Sigma Aldrich, Spruce Street, St Louis, USA) durante 1 hora. Os cortes passaram rapidamente pelo álcool absoluto, e então, permaneceram por 5 minutos nos álcoois 95\%, 70\%, respectivamente, e por último, receberam banhos com xilol ( $3 \times 5$ minutos). $E$ as lâminas foram montadas com Permount (Tuluene Solution, Fischer Scientific). As imagens com luz polarizadas foram geradas no microscópio Carl Zeiss modelo 25 ICS Standard (Carl Zeiss Microlmaging, LLC, Nova lorque, Estados Unidos) com câmera Canon modelo DS126151 acoplada ao microscópio. 


\subsubsection{Reações de Imunohistoquímica}

Os cortes foram desparafinizados e hidratados, e então lavados ( 3 x 5 minutos) com tampão fosfato $0,1 \mathrm{M}(\mathrm{pH}$ 7.4). O bloqueio da peroxidase endógena foi feito com solução H2O2 3\% (MERCK)/ Metanol (1:1) e após, o material lavado em tampão fosfato 0,1M. bloqueio dos sítios antigênicos inespecíficos foi realizado com albumina 10\% em tampão fosfato $0,1 \mathrm{M}$ durante 1 hora.

A incubação com anticorpo primário foi realizada por 16 horas à $4{ }^{\circ} \mathrm{C}$. Os anticorpos usados foram: Anti-Collagen type VI Polyclonal Antibody (Millipore) (1:100), Anti-Human Fibronectin Monoclonal Antibody (Millipore) (1:50), Rabbit Anti-rat Collagen type III Polyclonal Antibody (Chemicon, Millipore, CA) (1:100) e MMP2 Antibody (Invitrogen). As diluições foram realizadas em tampão fosfato $0,1 \mathrm{M} /$ Tween $20^{\circledR} 3 \%$.

O material foi lavado com tampão fosfato $0,1 \mathrm{M}$ ( $3 \times 5$ minutos) e em seguida, foi feita a incubação com anticorpo secundário Anti-Rabbit nas diluições 1:1000 (usado para os anticorpos para COL6), Anti- Mouse na diluição 1:200 (usado para os anticorpos para FN) (Santa Cruz Biotechnology). As lâminas foram incubadas com anticorpo secundário por 1hora e foram lavadas com tampão fosfato $0,1 \mathrm{M}$ por 3 vezes durante cinco minutos e, em seguida incubadas com o complexo terciário $A B C$ Peroxidase Staining Kit (Thermo Scientific, Rockford, USA), por 30 minutos em temperatura ambiente.

Por último, o material foi lavado novamente em tampão fosfato $0,1 \mathrm{M}$ e revelado com diaminobenzidina Metal Enhanced DAB Substrate Kit (Thermo Scientific, Rockford, USA). As lâminas foram montadas com Permount (Tuluene Solution, Fischer Scientific) e então, observadas no microscópio de luz Eclipse E800, Nikon e fotografadas com a câmera digital acoplada DXM1200C.

\subsubsection{Análise das Imagens}

A análise da morfologia das células, dos cortes histológicos, foi realizada nas imagens digitalizadas no aumento de 100x. As imagens foram obtidas utilizando um microscópio óptico (Leica, modelo DMLP), com câmera acoplada (LG - CCD- modelo GC-415N-MD). Para cada corte histológico foram capturadas 5 imagens coradas com hematoxilina-eosina por indivíduo. Para a análise morfométrica, foi considerada a área média, diâmetro médio e 
perímetro médio das células adiposas, sendo pelo menos 100 adipócitos por indivíduo, e as medidas foram então, analisadas com o software Image Pro-Plus 6.0.

\subsection{Microscopia Eletrônica de Transmissão}

Os fragmentos de tecidos de aproximadamente $2 \mathrm{~mm}^{3}$ foram fixados com em solução de glutaraldeído $3 \%(\mathrm{pH} 7.4)$ à temperatura ambiente e lavados posteriormente com tampão fosfato 0,1 M e, pós fixados com tetróxido de ósmio a 1,3\% durante 2 horas e, em solução a $0,5 \%$ de acetato de uranila overnight à $4{ }^{\circ} \mathrm{C}$.

O material foi então, desidratado em baterias crescentes de álcool etílico (70, 95 e 100\%, sendo dois banhos de 10 minutos em cada), e em óxido de propileno. A seguir, o material foi embebido em resina Spurr/ óxido de propileno na diluição 1:1, overnight, seguido de inclusão em resina pura durante 5 horas. $O$ material foi polimerizado em estufa a $60{ }^{\circ} \mathrm{C}$ por 48 horas. Os blocos receberam tratamento para obtenção dos cortes grossos e verificação da orientação dos mesmos.

Os cortes semi-finos de $250 \mathrm{~nm}$ de espessura foram obtidos em ultra-micrótomo, e foram corados com azul de tuloidina a $1 \%$ e observados no microscópio de luz. Os cortes ultra-finos de aproximadamente $70 \mathrm{~nm}$, levemente dourados, foram colhidos em telas de cobre de 200 malhas e contrastados com acetato de uranila 2\% em água destilada durante 5 minutos. A seguir, foram contrastados pelo citrato de chumbo durante 5 minutos. Os cortes ultrafinos foram observados no microscópio eletrônico de transmissão (Jeol, modelo 1010) e analisados com auxílio de um software de imagens Sigma Scan Pro.

\subsection{Quantificação da Expressão dos Genes COL1A1, COL3A1, COL6A1, FN1, MMP2, 18S pelo Método RT-PCR em Tempo Real}

\subsubsection{Extração de RNA}

Para isolar o RNA total foram usadas amostras do tecido adiposo subcutâneo dos pacientes, de massa entre 300 a 500 mg, armazenadas em TRIzol ${ }^{\circledR}$ Reagent. Estas foram homogeneizadas em aparelho Politron (modelo PT- MR 3100, Suíça), e a partir desta etapa, foram seguidas as instruções do fabricante. O RNA total foi tratado com $10 \mathrm{U}$ de 
deoxiribonuclease (RNase-free) por 1 hora a $37{ }^{\circ} \mathrm{C}$. Após o tratamento, realizou-se uma extração com igual volume da mistura contendo fenol-clorofórmio-alcool isoamílico na proporção de 25:24:1, seguida por precipitação com 0,2 M de acetato de sódio e 2 volumes de etanol absoluto. O RNA precipitado foi lavado com etanol 70\% para eliminar resíduos de fenol e sal e então, solubilizado em água DEPC. Para avaliação da concentração e pureza do RNA total foram realizados ensaios espectrofotométricos sob o comprimento de onda de 260 a 280 nm, a razão $A_{260 / 280}$ é proporcional à concentração de RNA total da amostra.

\subsubsection{Transcrição Reversa (RT)}

Para a síntese do cDNA utilizou-se $1 \mu \mathrm{g}$ de RNA total de cada amostra. As amostras foram incubadas com $0,5 \mu \mathrm{g} / \mathrm{ml}$ de OligosDTs (Invitrogen, USA) a $65{ }^{\circ} \mathrm{C}$ por 5 minutos a fim de obter a primeira fita de cDNA. A transcrição reversa foi realizada em um volume total de $20 \mu \mathrm{l} ; 10 \mathrm{mM}$ de dNTPs, 0,1 M de DTT, 5X Buffer (tampão da enzima), 3U de RNA inibitor e 2,5 U de M-MLV RT (enzima de transcriptase reversa). Após a incubação por 1 hora a $37^{\circ} \mathrm{C}$, a temperatura foi elevada a $95{ }^{\circ} \mathrm{C}$ por 5 minutos e as amostras EUA) as amostras, colocadas em termociclador Gene Amp- PCR System 9700 (Applied Biosystem- Life Techonologies, EUA), a $42{ }^{\circ} \mathrm{C}$ por 60 minutos (união dos nucleotídeos para formação e amplificação do cDNA) e a $95^{\circ} \mathrm{C}$ por 10 minutos (inativação da enzima RT) O cDNA obtido foi estocado a -20 ${ }^{\circ} \mathrm{C}$ até que fosse realizada a reação de PCR.

\subsubsection{Seleção dos Primers}

Todos os primers foram sintetizados pela Invitrogen ( Invitrogen, Carlsbad, California, EUA). A sequência foi determinada utilizando Real Time PCR Assay Design Tool (Integrated DNA Technologies, Inc), selecionados sempre de acordo com os seguintes parâmetros; com comprimento entre 18 e 24 pares de base (bp), com comprimento ótimo de 20-22 bases, $T_{m}$ entre 58 e $62{ }^{\circ} \mathrm{C}$, com temperatura ótima de $60{ }^{\circ} \mathrm{C}$ e comprimento do produto amplificado entre 150 a 200 bp. O conteúdo de CG foi entre 40 a 60\%, com conteúdo ótimo acima de $50 \%$ e neste caso, as sequências e bases repetidas (>3 bases) foram evitadas. Para avaliar a especificidade do primer, as sequências foram comparadas com o Genbank utilizando o programa Blast disponível no site da National Center for Biotecnology Information. Quando 
alguma, das sequências dos primers demonstraram homologia para um gene, diferente daquele de interesse, esta foi descartada. Todos os primers selecionados para o PCR foram desenhados para que o produto amplificado fosse sintetizado em éxons diferentes, evitando a contaminação de DNA genômico.

Tabela 1 - Sequências dos Primers para RT-PCR Tempo Real

\begin{tabular}{lll}
\hline Genes & Primer Sense & Primer Antisense \\
\hline COL 1A1 & TGTGGCCCAGAAGAACTGGTACAT & ACTGGAATCCATCGGTCATGCTCT \\
COL 3A1 & TGGAGAGTCCATGGATGGTGGTTT & AAGGAATGCCAGCTGCACATCAAG \\
COL 6A1 & AACTATGCAGAGCTGCTGGAGGAT & GAAGCGCTTGGTGGTGTCAAAGTT \\
FN1 & AGGACTGGCATTCACTGATGTGGA & AGCTCTGCAGTGTCTTCTTCACCA \\
MMP2 & AGAAGGATGGAAGTACGGCTTCT & AGTGGTGCAGCTGTCATAGGATGT \\
\hline $\mathbf{1 8 5}$ & CCTGCGGCTTAATTTGACTC & ATGCCAGAGTCTCGTCCGTT \\
\hline
\end{tabular}

\subsubsection{Reações de PCR em Tempo Real}

As reações de PCR em Tempo Real ocorreram utilizando $5 \mu$ l de DNA complementar adicionados a $2 \mathrm{x}$ SYBR ${ }^{\circledR}$ Green PCR Master Mix (Applied Biosystems, Life Technologies, EUA) e sequências específicas de oligonucleotídeos. A detecção por PCR em tempo real foi utilizada para determinação da expressão gênica dos colágenos I, III e VI ( COL1A1, COL3A1 e COL6A1, respectivamente), fibronectina (FN1) e MMP2 no tecido adiposo subcutâneo dos pacientes controle e tumor e caquexia. As reações de PCR em tempo real foram realizadas de acordo com Wang e Edens (2007), com o uso do detector de seqüência 7300 Real Time PCR System (Applied Biosystems, Life Technologies, EUA). A reação ocorreu com ciclagens pré- determinadas; duas etapas de 2 minutos a $50^{\circ} \mathrm{C}, 10$ minutos a $90^{\circ} \mathrm{C}$, a amplificação em 40 ciclos, a desnaturação a $95{ }^{\circ} \mathrm{C}$ por 15 segundos e anelamento a $63{ }^{\circ} \mathrm{C}$ por 60 segundos com extensão de $72{ }^{\circ} \mathrm{C}$ por 2 minutos. 
$O$ valor do $\Delta C_{t}$ foi obtido pela subtração do valor de $C_{t}$ do gene de interesse pelo valor do $C_{t}$ de $18 \mathrm{~s}$ (gene de referência) (BING et al., 2000). O valor médio dos $\Delta C_{t}$ do grupo controle (média de todos os sujeitos) foi então subtraído de cada amostra, gerando um novo valor denominado de $\Delta-\Delta C_{t}$. A expressão de cada gene foi avaliada por $2^{-(\Delta \Delta C t)}$.

\subsection{Parâmetros Plasmáticos}

\subsubsection{Triglicerídeos}

Os triglicerídeos plasmáticos (TAG) foram dosados pelo método colorimétrico (Kit Triglicerides Liquiform, Labtest, Lagoa Santa, MG, Brasil).

\section{$\underline{5.9 .2 \text { Uréia }}$}

A quantidade de uréia foi dosada pelo método enzimático colorimétrico (Labtest, Lagoa Santa, MG, Brasil).

\section{$\underline{5.9 .3 \text { Glicose }}$}

A dosagem de glicose plasmática foi realizada pelo método colorimétrico (Labtest, Lagoa Santa, MG, Brasil).

\subsubsection{Hemoglobina}

A dosagem de hemoglobina foi através de método colorimétrico. (Labtest, Lagoa Santa, MG, Brasil).

\subsubsection{Proteína C-Reativa}

A dosagem da proteína C reativa ocorreu no laboratório do HU por sistema de imunoturbidimetria realizadas na fração de soro (Labtest, Lagoa Santa, MG, Brasil). 


\subsection{Análise Estatística}

A análise dos dados foi realizada com utilização do software Graph Pad Prism (versão 5.0, Graph Pad,software, Inc). A média aritmética e o erro padrão ou desvio padrão foram calculados para todas variáveis estudadas. Os valores das diferentes análises foram avaliados pelo teste T de Student a dois fatores. Com esse tipo de análise os fatores foram avaliados como a diferença do efeito principal (efeito grupo controle vs grupo tumor com caquexia). 0 nível de significância adotado em todas as análises foi inferior a 5\%, ou seja, p<0,05. 


\section{RESULTADOS}

\subsection{Características Clínicas Gerais, Antropométricas e Parâmetros Plasmáticos}

As características clínicas gerais dos pacientes estão apresentadas na tabela 2. A idade, peso, altura e IMC não apresentaram diferenças entre os grupos. O grupo tumor com caquexia (TC) demonstrou significante perda de peso em relação ao grupo controle (C). A diferença entre o peso inicial e o peso final foi de $13.3 \pm 6.5 \mathrm{~kg}$ para o TC, enquanto $\mathrm{C}$ apresentou $0.8 \pm 1.0 \mathrm{~kg}$. Em adição, a perda de peso relativa no TC, também estava marcadamente diminuída em relação ao peso habitual $(20.6 \pm 8.5 \%$ e $3.4 \pm 0.2 \%$ para TC e C, respectivamente). A caquexia associada ao câncer é acompanhada de inflamação sistêmica, e um dos marcadores utilizados são os níveis de proteína C reativa, os pacientes do grupo TC estavam 20x maior. Esses resultados comprovam que os pacientes portadores de tumor realmente desenvolveram a síndrome da caquexia.

Tabela 2 - Características Clínicas Gerais, Antropométricas e Parâmetros Plasmáticos.

\begin{tabular}{lcc}
\hline & Tumor com Caquexia & Controle \\
Medidas & TC & C \\
\hline $\mathrm{N}$ & 17 & 20 \\
Sexo (Homens/ Mulheres) & $10-7$ & $11-9$ \\
Idade (anos) & $58.4 \pm 4$ & $51.1 \pm 3.6$ \\
IMC (kg.m-2) & $20.6 \pm 0.8$ & $23.3 \pm 0.9$ \\
Perda de Peso (\%) & $19.9 \pm 1.9$ & $1.94 \pm 1$ \\
Hemoglobina & $11.4 \pm 0.4$ & $12.4 \pm 0.5$ \\
Proteína C Reativa (mg/dl) & $92 . \pm 15.4^{*}$ & $50.8 \pm 40.9$ \\
Uréia (mg/dl) & $35.3 \pm 6.5$ & $36.9 \pm 2.7$ \\
Glicose(mg/dl) & $120.6 \pm 9.1$ & $107.5 \pm 6.9$ \\
\hline Triglicerídeos & $81.4 \pm 18.3$ & $104.2 \pm 21.7$ \\
\hline Dados como media
\end{tabular}

Dados como média e desvio padrão. * $p<0,05$ em relação a $C$. 


\subsubsection{Aspectos Morfológicos do Tecido Adiposo}

A figura 1 ilustra a morfologia do tecido adiposo subcutâneo dos grupos TC e C. Os aspectos morfológicos observados nos pacientes com caquexia associada ao câncer encontram-se modificados. Enquanto, no grupo C, os adipócitos são característicos e esféricos, demonstram uma fina camada de citoplasma, e o núcleo restrito a parte periférica da célula com a presença de uma grande gotícula lipídica. Já, no grupo TC, os adipócitos perderam a característica da forma esférica da célula, e se tornaram mais poligonais. Além disso, a MEC no grupo TC está claramente modificada, em que podemos notar o espaço intersticial aumentado acompanhado de uma marcada fibrose.
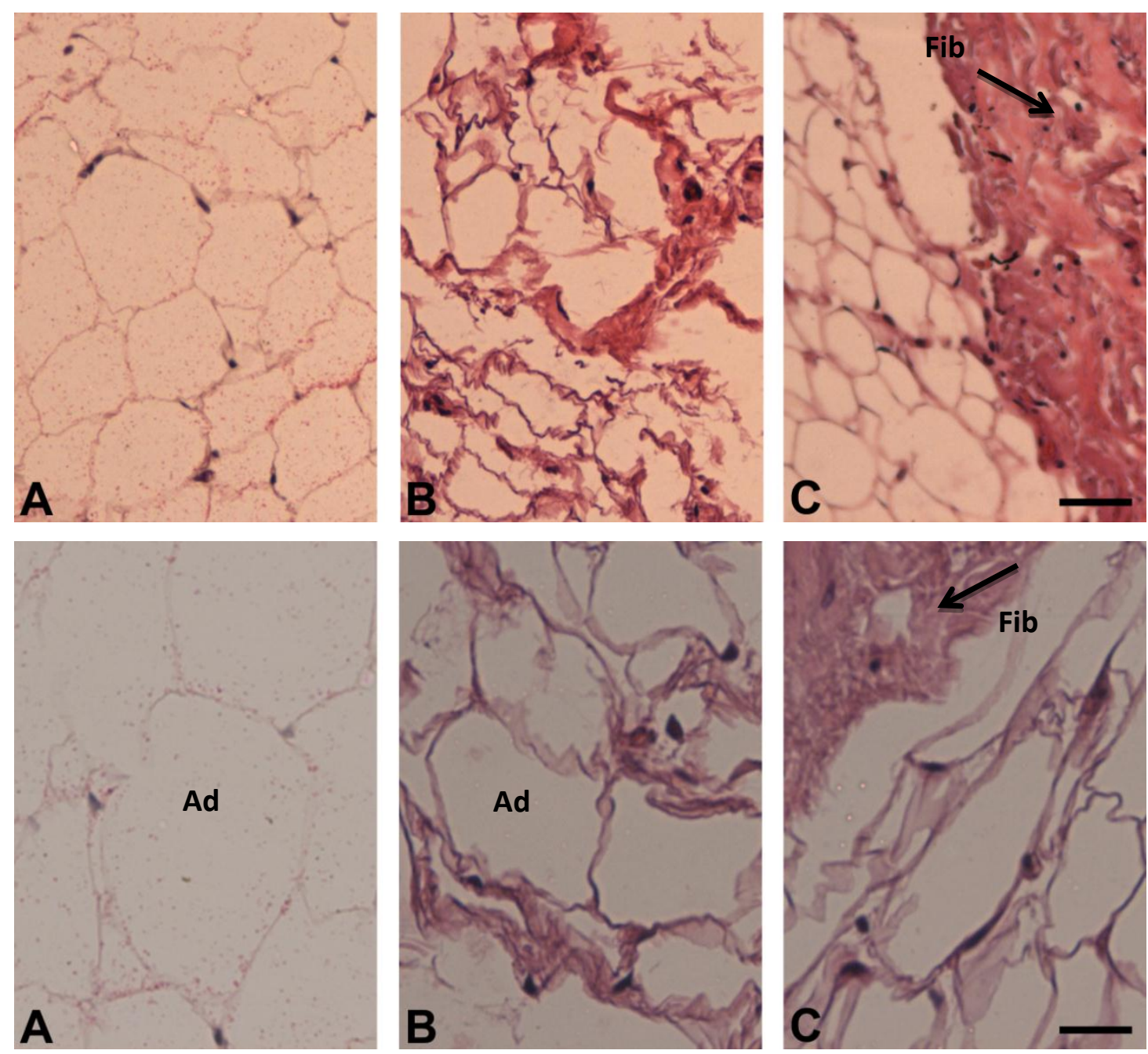

Figura 2. Características Morfológicas do Tecido Adiposo Subcutâneo. Coloração com hematoxilina e eosina do grupo $C(A)(n=5)$ e do grupo TC $(B, C)(n=5)$. Adipócito (Ad). Áreas com fibrose (Fib). Barras $=112,5 \mu \mathrm{m} ; 120 \mu \mathrm{m}$ respectivamente. 


\subsubsection{Análises Morfométricas dos Adipócitos}

Os resultados das análises morfométricas estão representados na figura 2. As áreas dos adipócitos estavam $55 \%$ vezes menores em TC com relação a $C(p<0,05)$. 0 diâmetro e o perímetro, também acompanharam a redução encontrada na área, sendo menores $24 \% \mathrm{e}$ $25 \%$ vezes em TC com relação a $C(p<0,05)$, respectivamente, representados na figura 3.

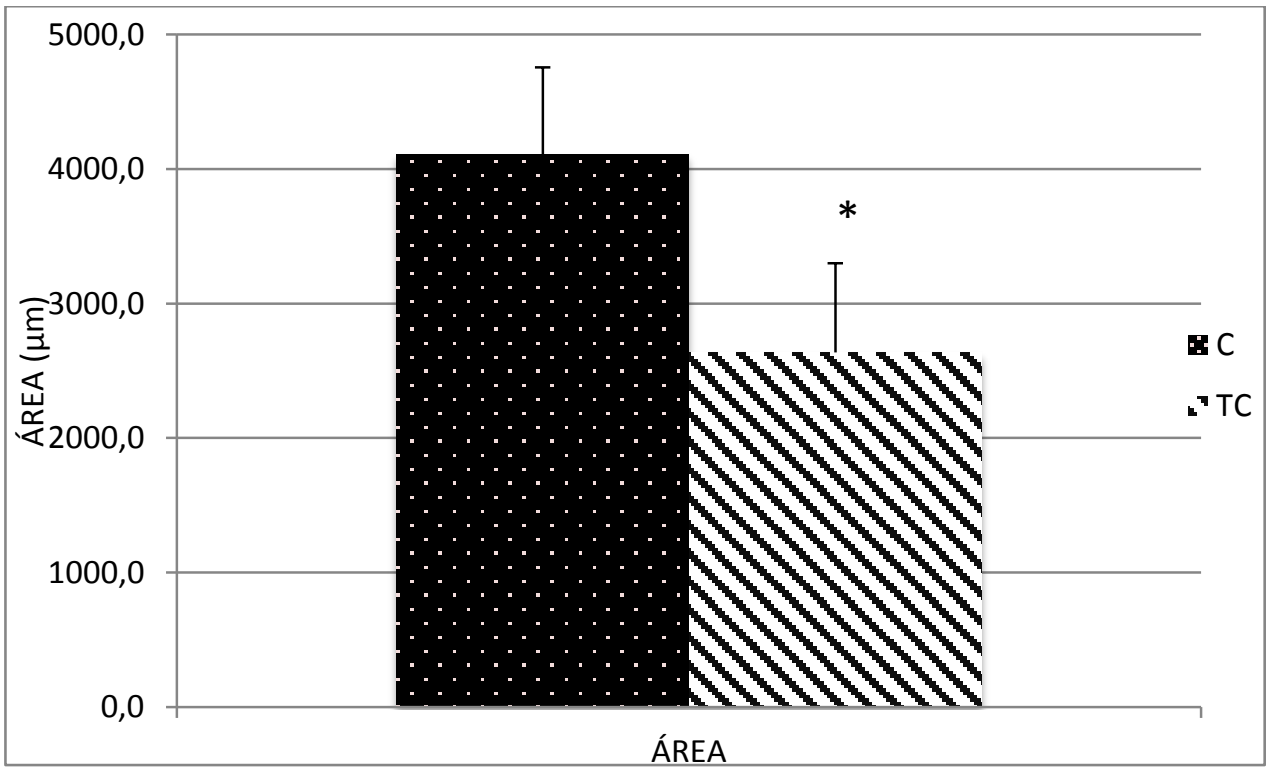

Figura 3. Morfometria dos Adipócitos- Área. Grupo controle (C) $(n=4)$ e tumor com caquexia (TC) $(n=5)$ (100 adipócitos por indivíduo). * $p<0,05$.

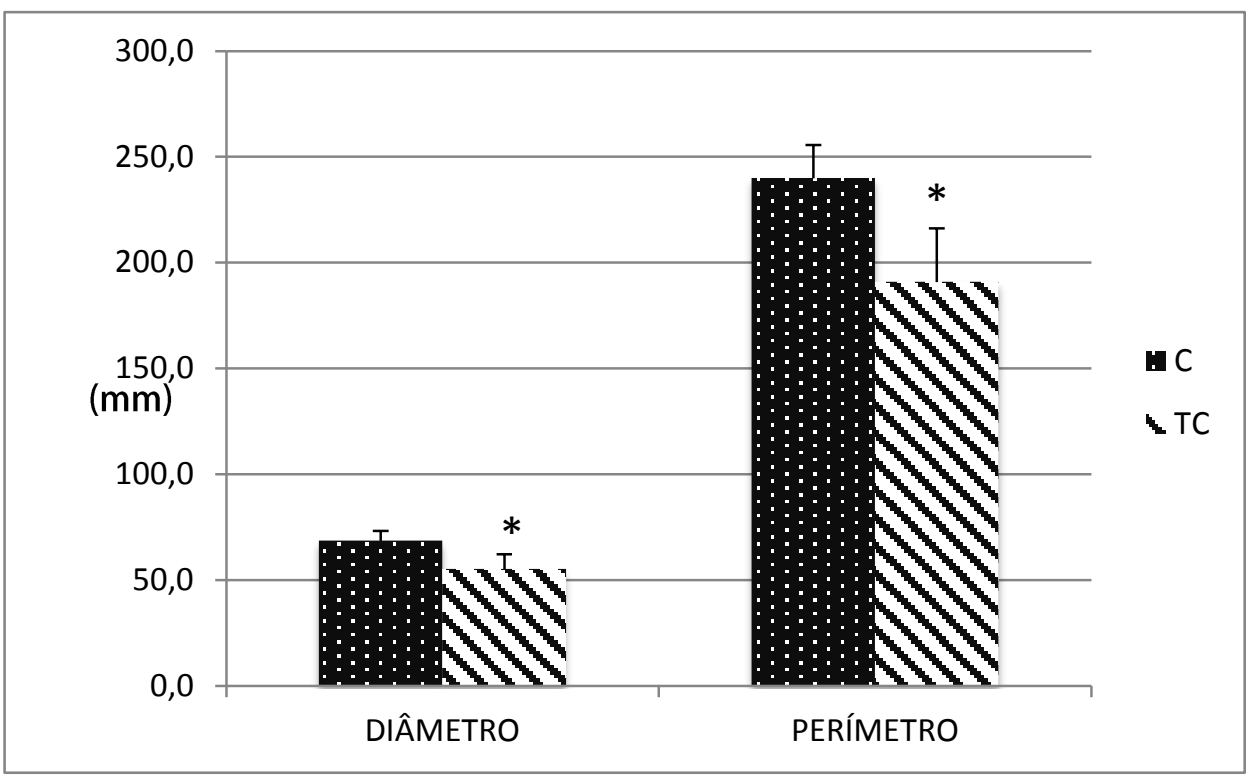

Figura 4. Morfometria dos Adipócitos- Diâmetro e Perímetro. Grupo controle (C) $(n=4)$ e tumor com caquexia (TC) ( $n=5)\left(100\right.$ adipócitos por indivíduo). ${ }^{*} p<0,05$. 


\subsection{Aspectos Ultraestruturais do Tecido Adiposo}

A ultraestrutura dos adipócitos do tecido adiposo subcutâneo está ilustrada na figura 5. Não foi observada diferenças na ultraestrutura dos adipócitos entre os grupos estudados.

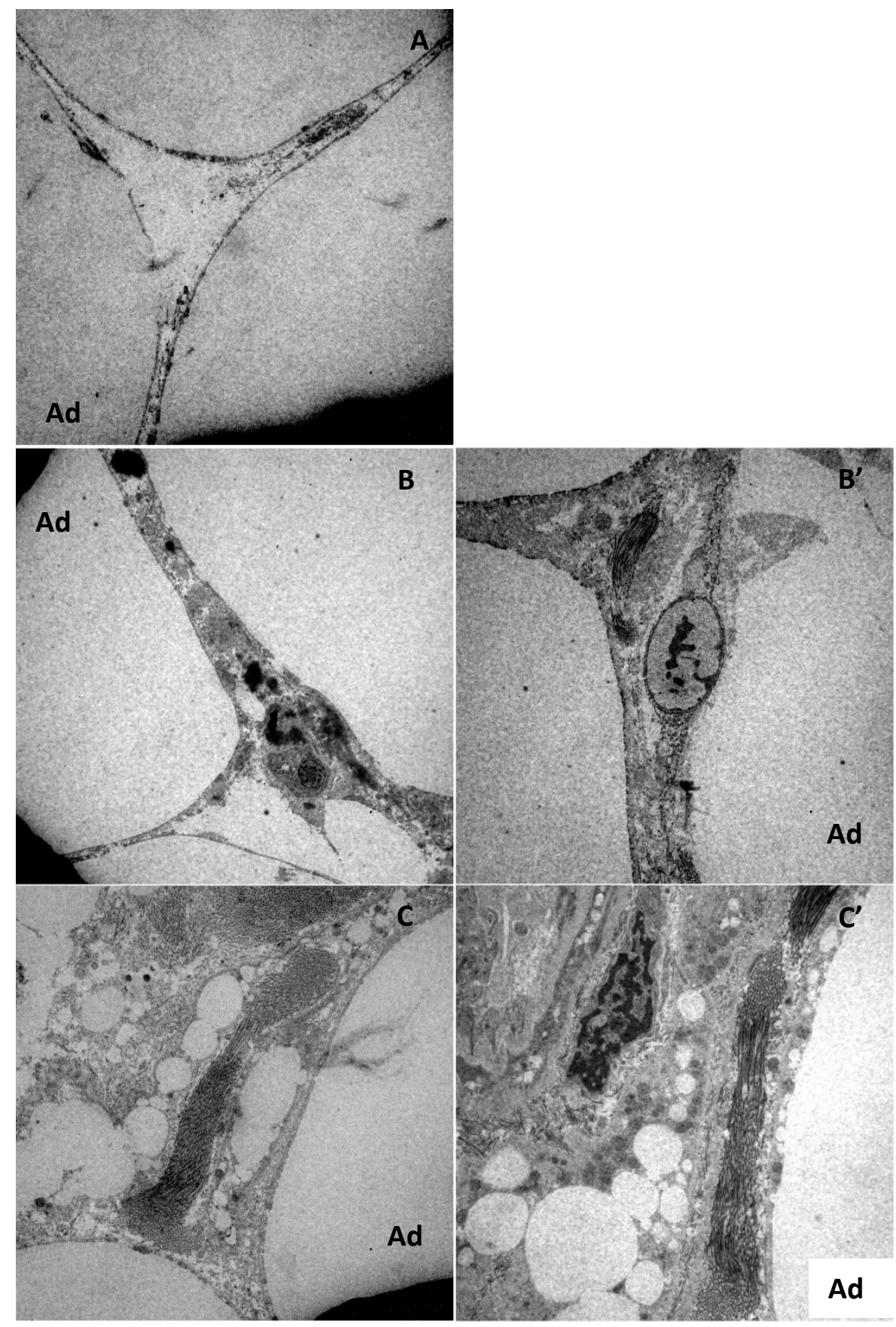

Figura 5. Ultra-estrutura do Tecido Adiposo Subcutâneo. Grupo Controle (A) (aumento de 3000x), Grupo Tumor com Caquexia (B, B', C, C') (B - aumento de 1200x; B' - aumento de 3000x; Caumento de 5000x; $C^{\prime}-$ aumento de 7500x).Adipócito (Ad). 


\subsection{Detecção de Colágeno com Coloração por Picro Sirius Red}

A coloração por Picro Sirius Red foi usada para detectar o conteúdo de colágeno presente no tecido adiposo subcutâneo dos grupos C e TC demonstrados na figura 5. A forte presença de colágeno foi observada no espaço intersticial do tecido no grupo TC, e fica mais evidente ainda, nas áreas com fibrose tecidual.
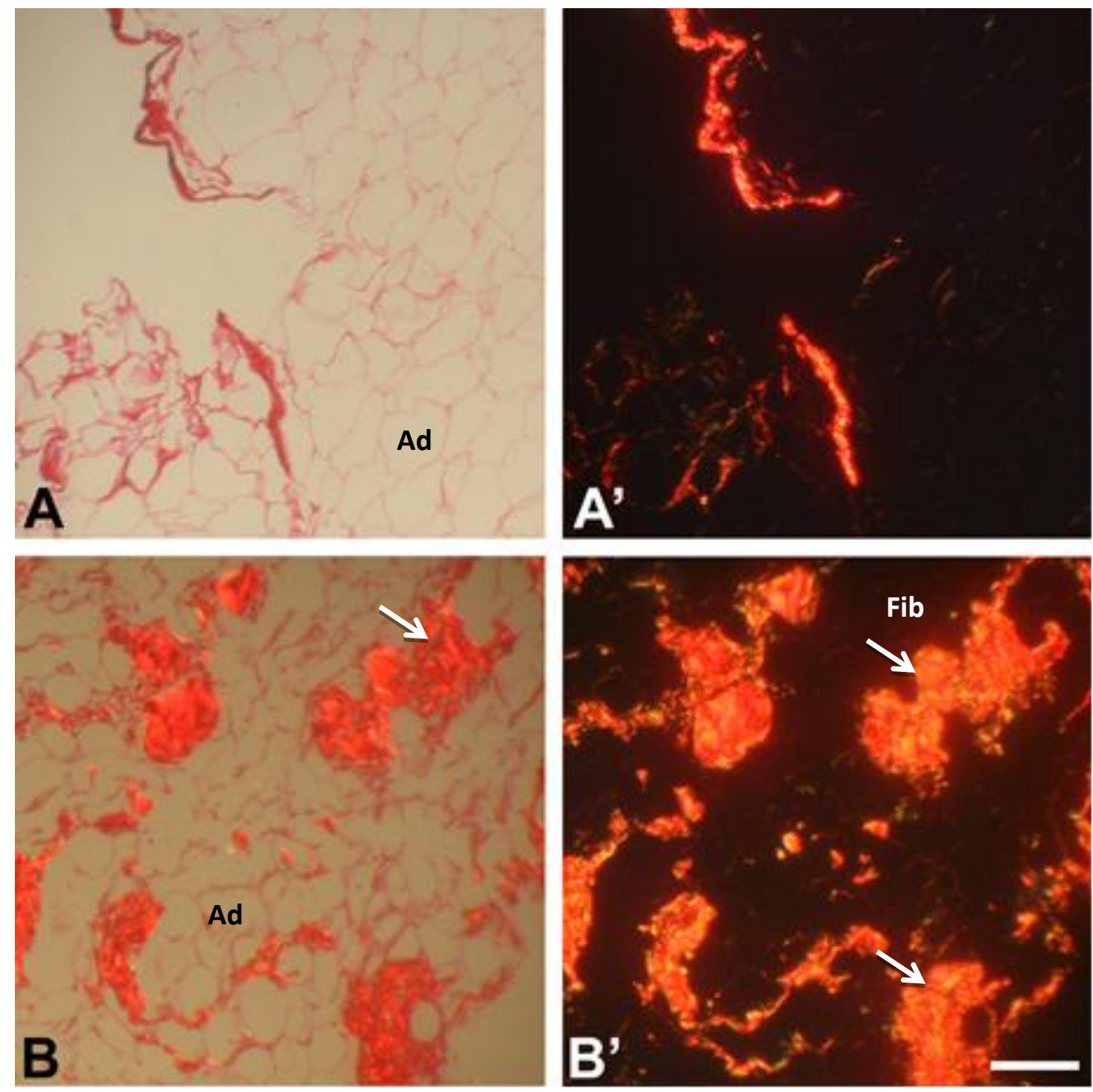

Figura 6. Detecção de colágeno com coloração por Picro Sirius Red do Tecido Adiposo Subcutâneo. Imagens dos grupos: Controle $(A)(n=5)$ e TC $(B)(n=5)$ fotografadas com microscopia de luz, e com luz polarizada ( $A^{\prime}$; $B^{\prime}$, respectivamente) Barra=137,5 $\mu$ m. Adipócito (Ad). Fibrose (Fb). Observar as áreas com deposição de colágeno e formação de fibrose indicadas. 


\subsection{Expressão Gênica pelo Método RT-PCR em Tempo Real}

Todos os dados de expressão gênica foram expressos em relação à expressão do gene 18s (controle interno) para cada gene, cujos valores foram definidos como 1.

\subsubsection{PCR em Tempo Real para o Gene COL1A1}

A figura 6 ilustra a expressão gênica do COL1A1 no tecido adiposo subcutâneo. A expressão gênica do COL1A1 no tecido adiposo subcutâneo não apresentou diferença estatística entre os grupos estudados.

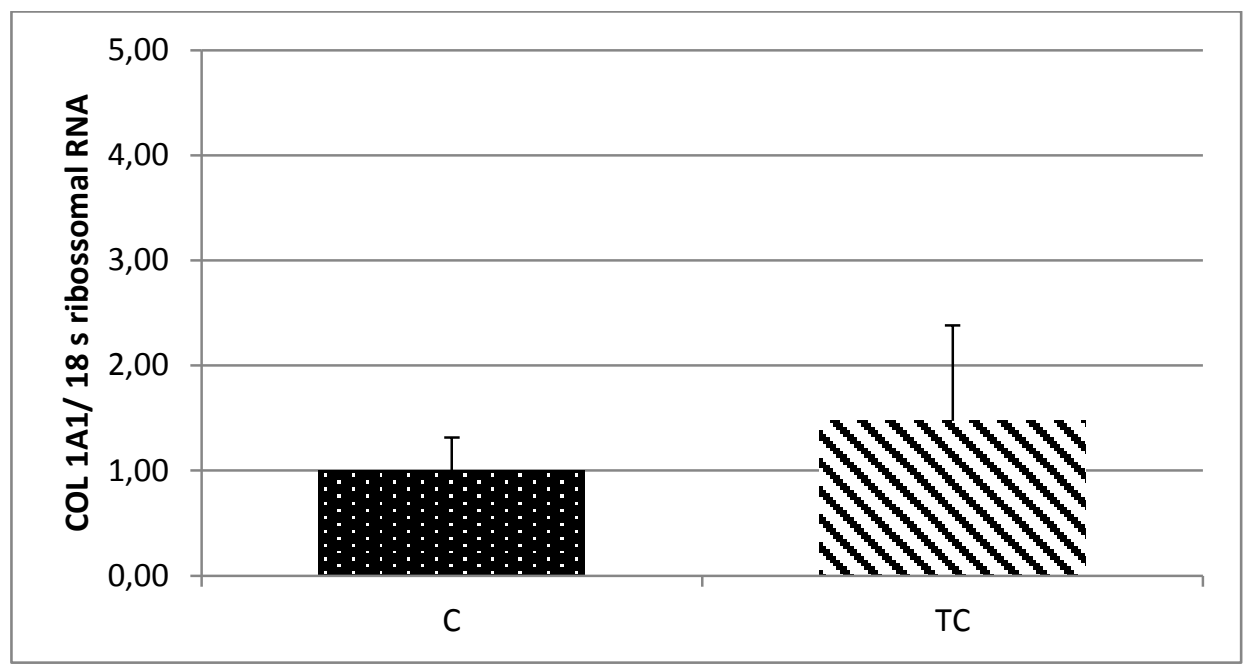

Figura 7. Expressão Gênica em tempo real do gene COL1A1 no Tecido Adiposo Subcutâneo. Grupo Controle ( $n=12$ ) e Grupo Tumor com caquexia $(n=8)$. Dados como média e erro padrão.

\subsubsection{PCR em Tempo Real para o Gene COL3A1}

A expressão gênica do COL3A1 em relação à expressão do gene 18s não demonstrou diferença significativa entre os grupos C e TC. 


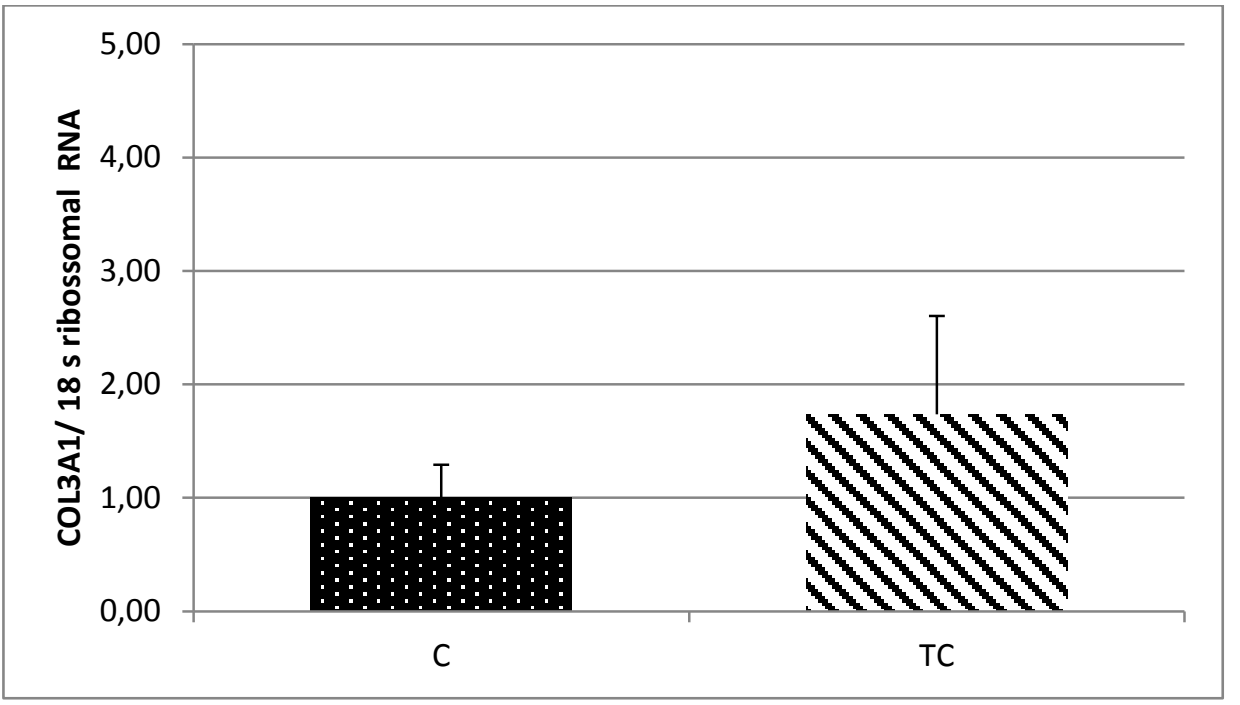

Figura 8. Expressão Gênica em tempo real do gene COL3A1. Grupo Controle ( $n=14)$ e Grupo Tumor com Caquexia $(n=8)$. Dados como média e erro padrão.

\subsubsection{PCR em Tempo Real para o Gene COL6A1}

A figura 8 demonstra a expressão gênica do COL6A1 em relação ao gene 18s. O grupo TC apresentou um aumento significativo de $21 \%$ em relação a C.

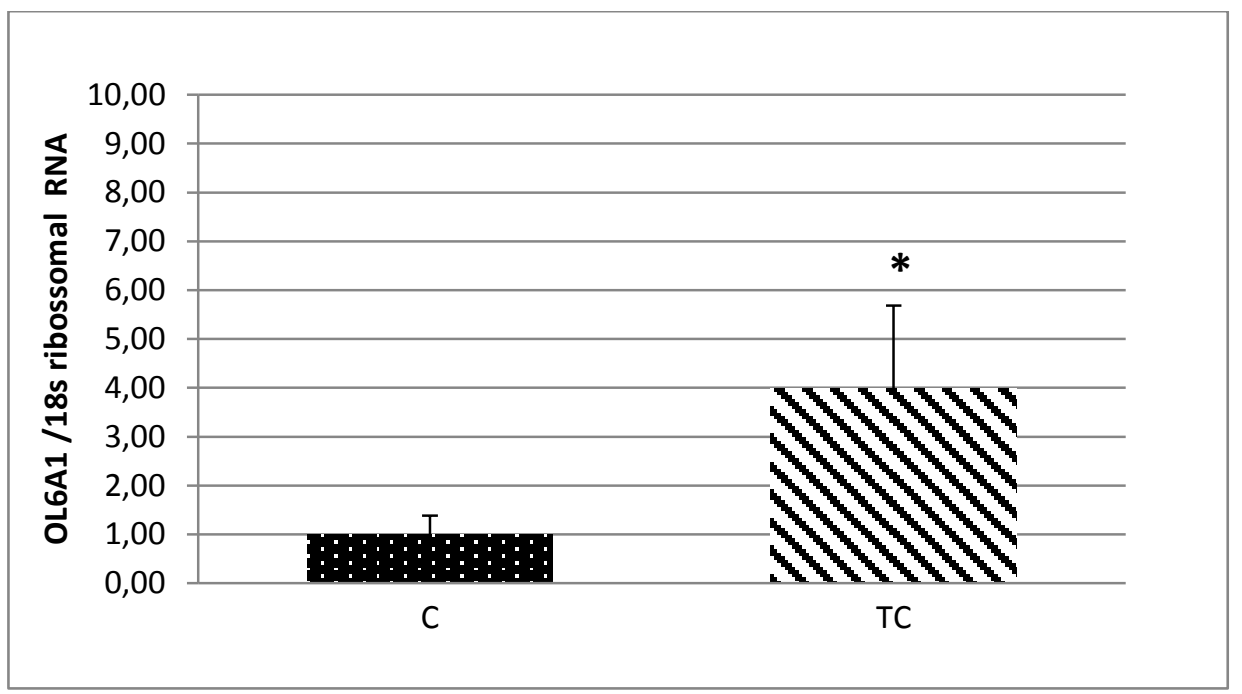

Figura 9. Expressão Gênica em tempo real do gene COL6A1. Grupo Controle $(n=14)$ e Grupo Tumor com Caquexia $(n=8)$. Dados como média e erro padrão. ${ }^{*} p<0,05$ em relação a $C$. 


\subsubsection{PCR em Tempo Real para o Gene FN1}

A expressão gênica da FN1 no tecido adiposo subcutâneo está ilustrada na figura 10. Houve um aumento significativo $(p<0,05)$ dos valores do grupo TC em relação a $C$.

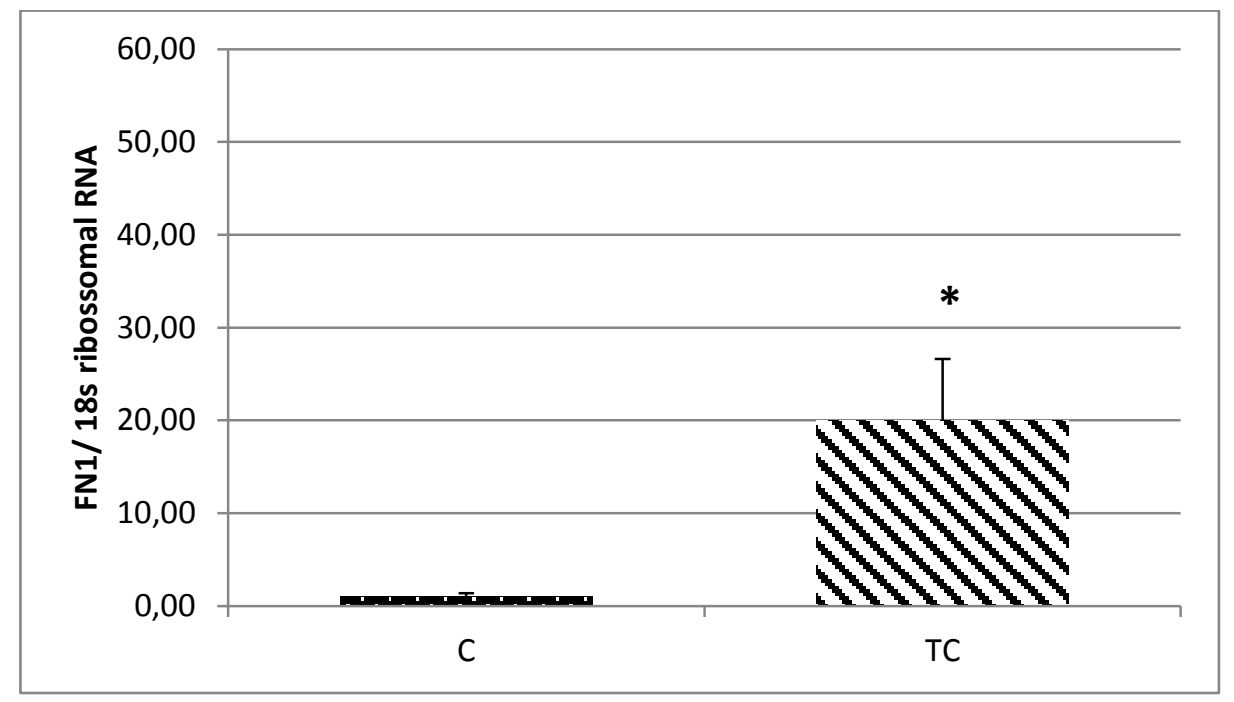

Figura 10. Expressão Gênica em tempo real do gene FN1. Grupo Controle $(n=12)$ e Grupo Tumor com Caquexia $(n=6)$.Dados como média e desvio padrão. ${ }^{*} p<0,05$ em relação $C$.

\subsubsection{PCR em Tempo Real para o Gene MMP2}

Os resultados obtidos pela expressão gênica da MMP2 demonstram que mRNA está reduzido 30\% no TC em relação a C, e estão apresentados na figura 11.

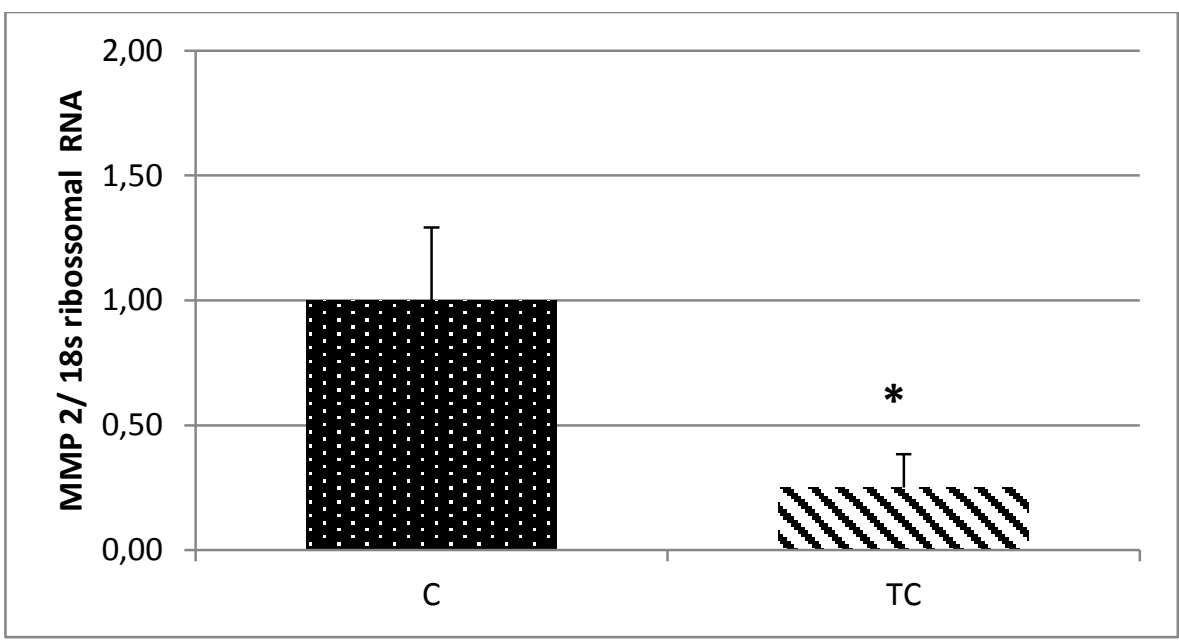

Figura 11. Expressão Gênica em tempo real para o gene MMP2. Grupo Controle $(n=8)$ Grupo Tumor com Caquexia $(n=9)$. Dados como média e erro padrão. ${ }^{*} p<0,05$ em relação a $C$. 


\subsection{Imunohistoquímica para Colágeno tipo III}

A imunohistoquímica para colágeno do tipo III está representada na figura 12 , evidenciando a presença dessa proteína no tecido adiposo subcutâneo em humanos. Podemos observar a marcação do colágeno III em ambos os grupos, no entanto é mais notável no TC.

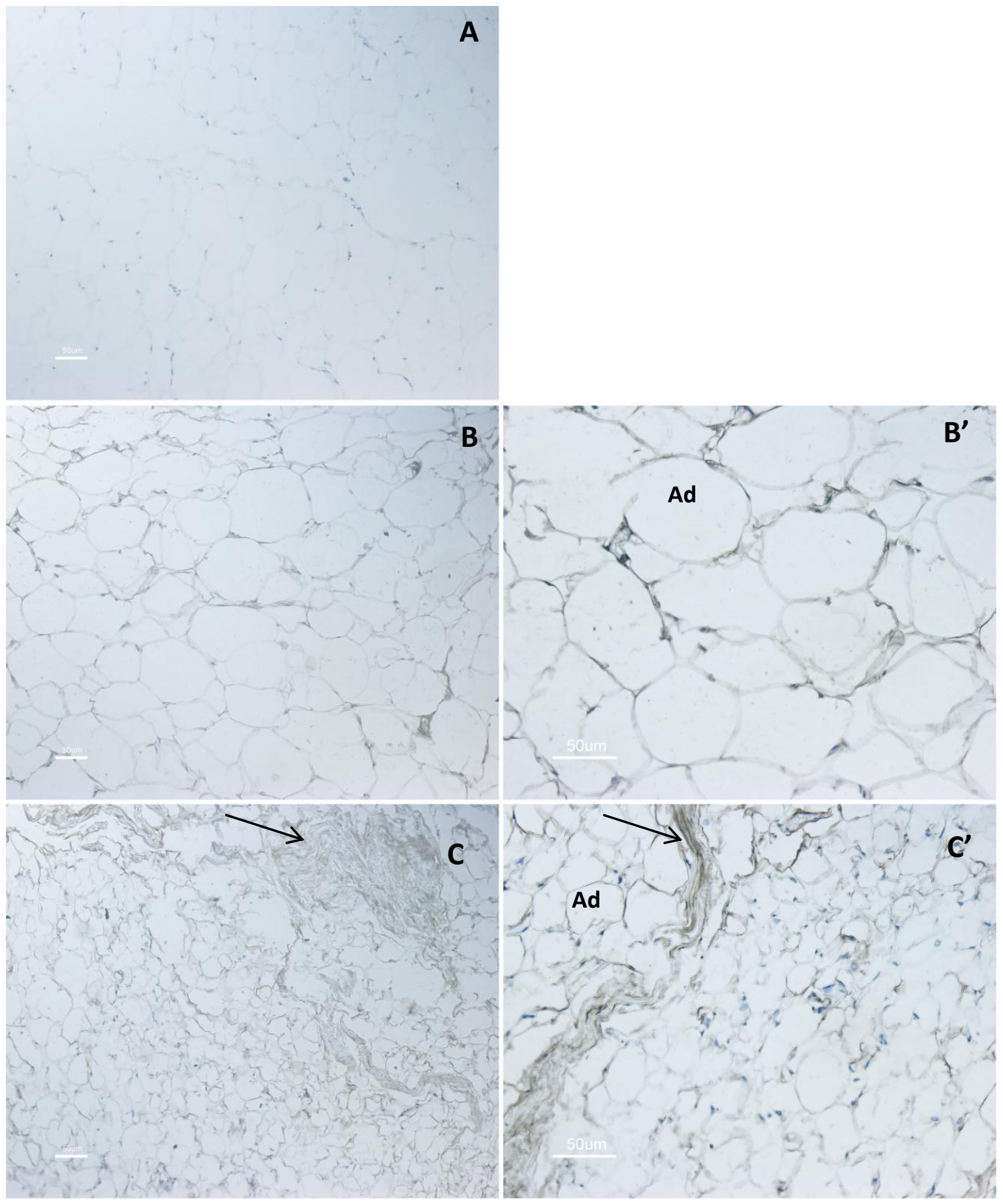

Figura 12. Imunohistoquímica para Colágeno III no Tecido Adiposo Subcutâneo. Controle Negativo (A), Grupo Controle $\left(B, B^{\prime}\right)(n=3)$, Grupo Tumor com Caquexia $\left(C, C^{\prime}\right)(n=3)$. Adipócito (Ad). Notar a deposição de colágeno no grupo TC, em áreas demarcadas entre as células. 


\subsection{Imunohistoquímica para Colágeno tipo VI}

Imunohistoquíca para colágeno VI no tecido adiposo subcutâneo. Foi observada uma forte imunopositividade no grupo TC em comparação ao $C$, indicando que houve o aumento do colágeno VI. 


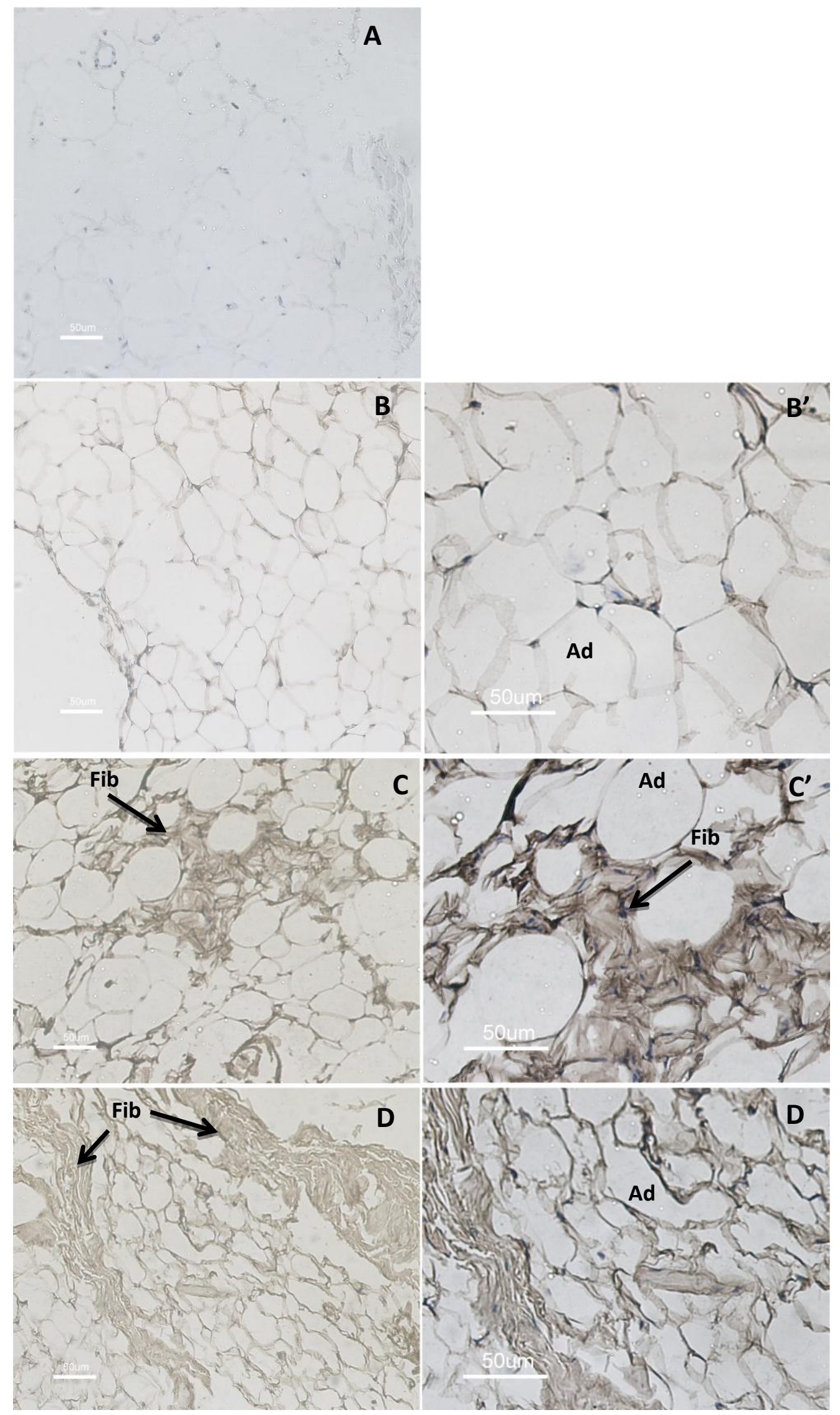

Figura 13. Imunohistoquímica para Colágeno VI no Tecido Adiposo Subcutâneo. (A) Controle Negativo, (B, B') Grupo Controle $(n=5),\left(C, C^{\prime}, D, D^{\prime}\right)$ Grupo Tumor com Caquexia $(n=5)$. Adipócito (Ad). Fibrose (Fb). Notar a abundância na deposição de colágeno no grupo TC. 


\subsection{Imunohistoquímica para Fibronectina}

Foi observada a imunopositividade em ambos os grupos, contudo houve maior marcação em TC presente nas áreas com fibrose tecidual.

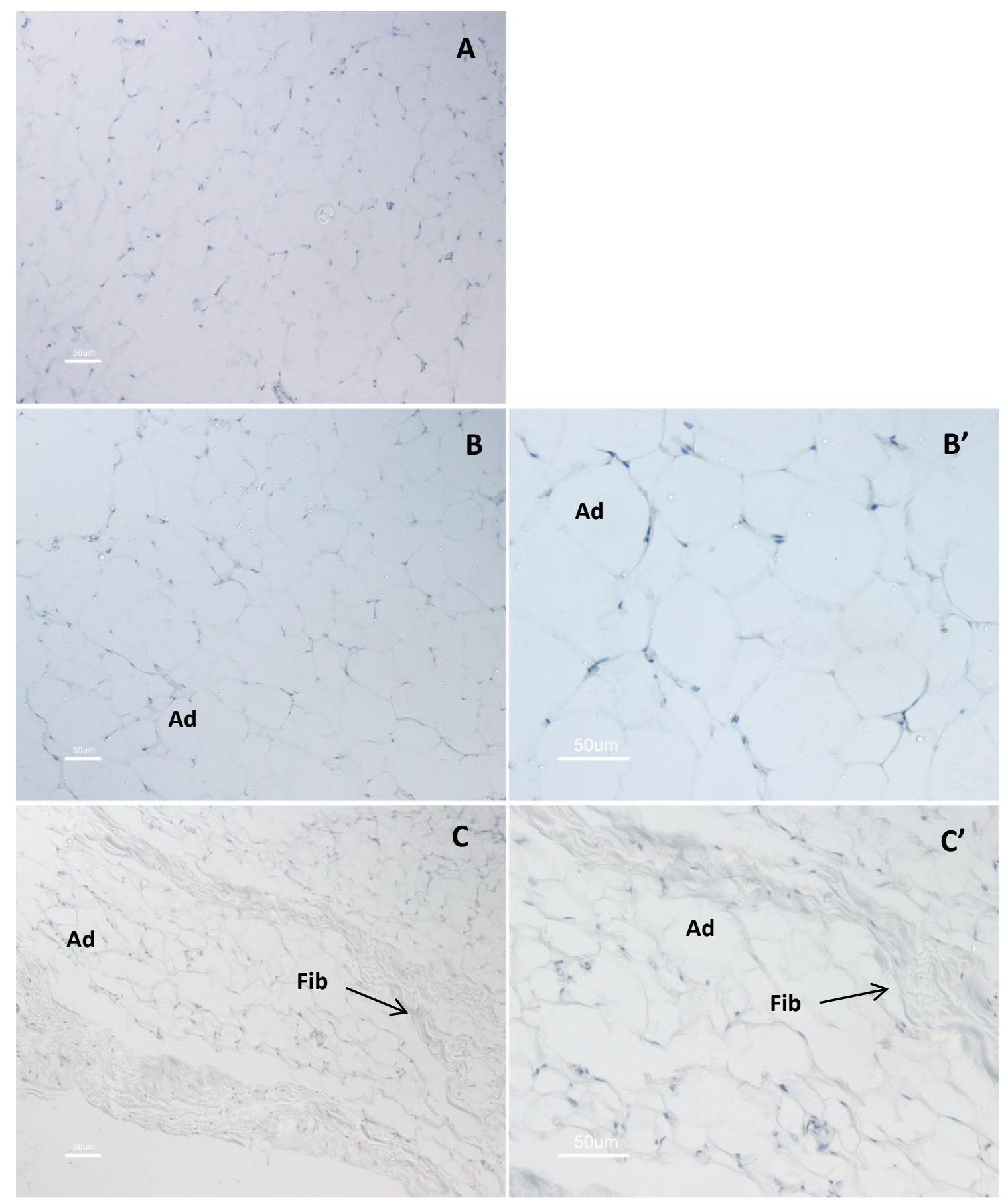

Figura 14. Imunohistoquímica para Fibronectina no Tecido Adiposo Subcutâneo. Controle negativo (A), Grupo Controle $\left(B, B^{\prime}\right)(n=5)$, Grupo Tumor com Caquexia $\left(C, C^{\prime}\right)(n=5)$. Adipócito (Ad). Fibrose(Fib). Observe o conteúdo demarcado entre os adipócitos no grupo TC. 


\subsection{Imunohistoquímica para MMP2}

A imunohistoquímica para MMP2 no tecido adiposo subcutâneo está apresentada na figura 15. Foi observado maior imunopositividade no grupo $C$ comparado ao TC.

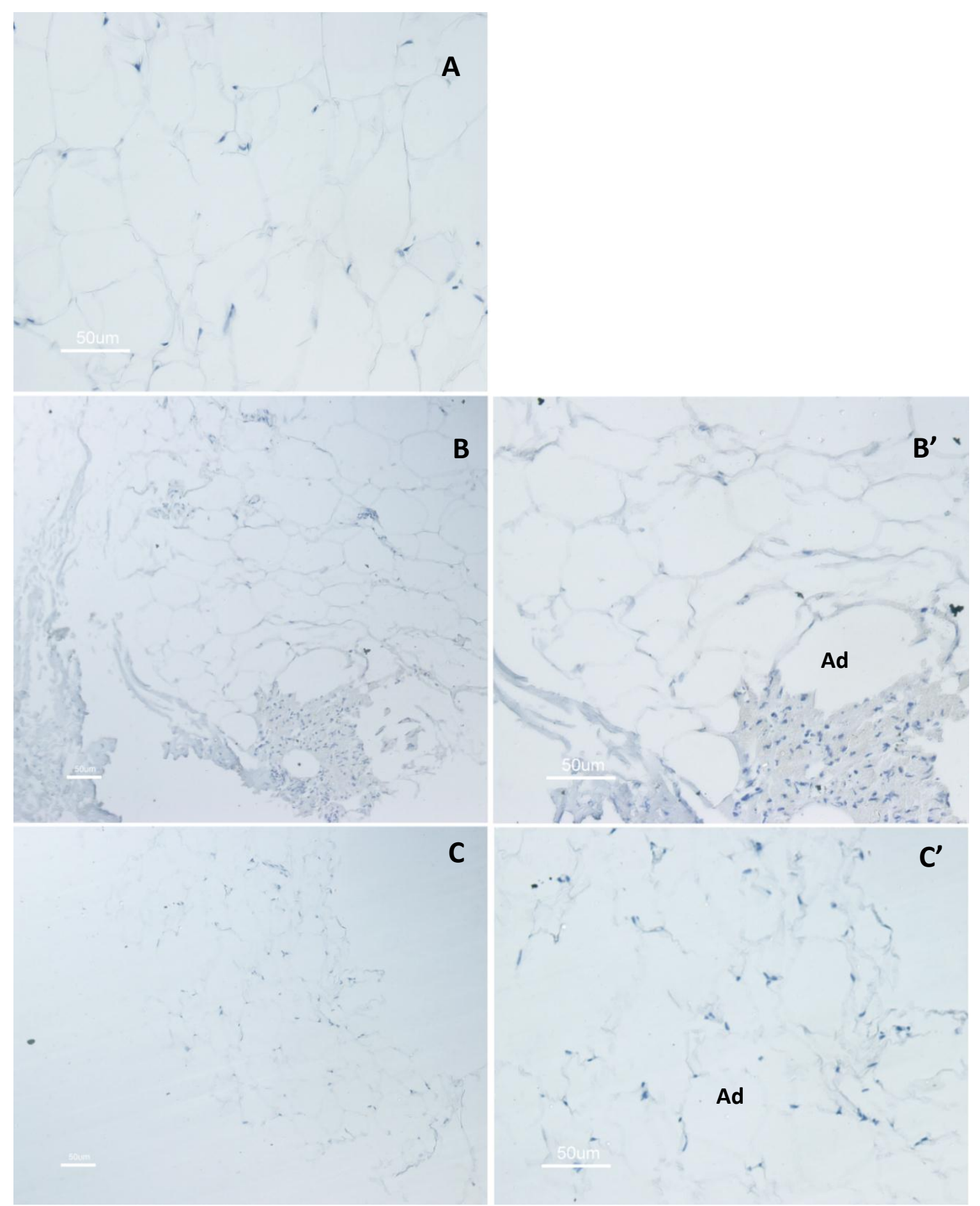

Figura 15. Imunohistoquímica para MMP2 no tecido adiposo subcutâneo. Controle Negativo (A), Grupo Controle (B, $\left.B^{\prime}\right)(n=3)$ e Grupo Tumor com Caquexia $\left(C, C^{\prime}\right)(n=3)$. Adipócito (Ad). Observe a pouca marcação no grupo TC. 


\section{DISCUSSÃO}

A caquexia associada ao câncer é talvez a manifestação mais comum de câncer avançado, sendo acompanhada por preferencial perda de tecido adiposo (BING et al., 2009). Em condições normais, o tecido adiposo é considerado tecido conjuntivo frouxo e de alta plasticidade, com funções, tais como, armazenamento de gordura, proteção mecânica e síntese da vasta gama de fatores (POND, 1999; TILG; MOSCHEN, 2006). Estas funções são influenciadas pelas demandas específicas deste tecido e a MEC desempenha um papel importante na regulação da função dos adipócitos (MARIMAN E WANG, 2010).

O objetivo do presente estudo foi avaliar os efeitos da caquexia associada ao câncer sobre os componentes da matriz extracelular do tecido adiposo de pacientes caquéticos portadores de tumor e compará-los com pacientes não cáqueticos. Ao nosso conhecimento, este é o primeiro estudo que objetivou avaliar os aspectos morfológicos do tecido adiposo de humanos e a contribuição de alguns componentes da MEC em resposta à síndrome.

Nossos principais achados mostram capciosas alterações morfológicas concomitantes a alterações no conteúdo de colágeno, em especial o tipo VI, encontradas no tecido adiposo do grupo tumor com caquexia. O tecido adiposo subcutâneo analisado não é adjacente ao tumor, e ainda assim, apresentou importantes modificações exaltando sua relevância, sofrendo, portanto, um efeito sistêmico da caquexia.

A perda de peso não intencional ( $\geq 5 \%$ do peso total corpo) acompanhada de alterações no IMC e os altos níveis de proteína C reativa são características do desenvolvimento da síndrome de acordo com Morley et al. (2006), e os resultados obtidos no presente estudo demonstram que, realmente, os pacientes estavam caquéticos no grupo TC. Enquanto que o grupo C não apresentou variações na perda de peso e IMC (tabela 1). Infelizmente não avaliamos a quantidade de gordura corporal perdida desses pacientes.

Estudos anteriores realizados pelo nosso grupo (BERTEVELLO; SEELAENDER, 2001; MACHADO et al., 2004) relatam que a morfologia do tecido adiposo encontrava-se alterada frente a presença da síndrome em modelos animais. No presente estudo, com o uso da microscopia de luz com a coloração de hematoxilina-eosina, foi possível observar alterações na forma esférica típica dos adipócitos no grupo TC, com a prevalência de célula de forma poligonal, além do aumento no conteúdo de matriz extracelular entre as células e o 
aparecimento de áreas isoladas com deposição de matriz. Esses resultados são consistentes com os nossos estudos anteriores.

Bing et al. (2006) utilizando modelo animal, também relatou profundas mudanças na morfologia do tecido adiposo junto com a redução no tamanho do adipócitos e áreas fibróticas na caquexia associada ao câncer. As análises morfométricas evidenciaram a redução na área, diâmetro e perímetro nos adipócitos dos pacientes do grupo TC, consistentes com o estudo de Bing et al. (2006), e diferentemente no modelo tumoral de Walker 256, que Bertevello e Seelaender (2001) mostraram o aumento na área dos adipócitos nos ratos caquéticos.

O aumento de fatores produzidos pelo tecido adiposo de humanos em vigência da caquexia, tais como a interleucina 6 (IL-6) e o fator de necrose tumoral (TNF- $\alpha$ ), bem como a atividade enzimática da lipase hormônio sensível (LSH) que é uma enzima chave na regulação da lipólise contribuem para o aumento da lipólise (AGUSTSSON et al., 2007; RYDÉN et al., 2008). Logo, podem estar relacionados com essa diminuição na área, diâmetro e perímetro dos adipócitos.

Para caracterizar essas áreas que surgiram entre os adipócitos, com grande deposição de matriz, realizamos a coloração por Picro Sirius Red. O uso dessa coloração é recomendado para demarcar fibras de colágeno (PUCHTLER et al., 1988). Os resultados mostraram intensa coloração no TC, e ainda, mais intensa nas áreas com deposição de matriz, quando observadas sob a luz polarizada. O aumento do conteúdo de colágeno está abertamente associado com fibrose tecidual (DIVOUX; CLÉMENT, 2011).

Estudos realizados com pacientes caquético com referência ao perfil de expressão gênica mostraram modificações da expressão de genes relacionados a adesão celular, matriz extracelular e citoesqueleto (DAHLMAN et al., 2010). No presente estudo, os pacientes portadores de tumor com caquexia apresentaram o aumento na expressão gênica do COL6A1 $(p<0,05)$, no entanto, os genes COL1A1 e COL3A1 não demonstraram diferenças significativas. Porém, foi observada através da imunohistoquímica, maior presença do colágeno III no grupo TC comparado com C. Em acordo com o aumento da expressão gênica, a imunopositividade para o colágeno $\mathrm{VI}$ estava exacerbada nos pacientes caquéticos contribuindo para um dos achados mais interessantes do estudo, uma vez que, as alterações na expressão do colágeno VI são encontradas em um quadro oposto da caquexia, a obesidade (PASARICA et al., 2009). 
O colágeno $\mathrm{VI}$, entre outras proteínas da matriz do tecido adiposo, está associado também, a marcadores de inflamação e a infiltração de macrófagos em indivíduos obesos (KEOPHIPHAT et al., 2009; PASARICA et al., 2009; SPENCER et al., 2010). Em estudos realizados pelo nosso grupo de pesquisa com animais caquéticos evidenciam da mesma maneira, a presença da infiltração de macrófagos, e estes, estão relacionados com aumento de citocinas, como TNF- $\alpha$, sugerindo a possível participação desses na regulação da matriz de tecido adiposo (LIRA et al., 2009; MACHADO et al., 2004).

Mariman e Wang (2010) propõem que colágeno VI é expresso mais especificamente no tecido adiposo e a presença de todas suas subunidades $\alpha 1, \alpha 2$, e $\alpha 3$ é necessária para garantir sua estabilidade. A síntese nas fases iniciais parece um requisito permissivo para o início da diferenciação adipócito, e a síntese do colágeno nos estágios finais da diferenciação pode estar relacionada com funções específicas dos adipócitos e do tecido adiposo, e ainda, é especulado que o colágeno tipo VI contribui para o acúmulo de gordura na gotícula lipídica.

Recentemente, Khan et al. (2009) observaram alterações graves dos componentes da matriz extracelular no tecido adiposo de pacientes obesos, em especial do colágeno $\mathrm{VI}$, constituindo a presença de fibrose no tecido adiposo, iniciada em resposta a hipertrofia do adipócito. Os autores discutem que, na obesidade, esse aumento da rigidez da matriz do tecido adiposo neutraliza a tendência de expansão de adipócitos, podendo então, exercer uma enorme pressão sobre a membrana plasmática, e, portanto, levando à morte celular por necrose. A alteração no conteúdo de colágenos no tecido adiposo resulta no aumento de rigidez do tecido e da resistência mecânica sendo denominada de fibrose tecidual. Apesar de o adipócito estar hipotrófico na caquexia associada ao câncer, podemos especular a ocorrência de mecanismos de regulação similares para duas síndromes tão opostas que resultam nas alterações no conteúdo de colágeno, observado em ambas as síndromes.

Ainda, corroborando com nossos achados, Henegar et al. (2008) observaram que em indivíduos obesos houve um aumento da fibrose intersticial no tecido adiposo, esse material de conteúdo fibrótico estava localizado ao redor dos adipócitos formando áreas amorfas com deterioração do tecido que também foram observadas em nosso estudo. Esses indivíduos obesos sofreram procedimento cirúrgico, a fim de induzir a redução de peso e, meses após essa redução do peso, as áreas com fibrose ainda estavam presentes no tecido. 
Na revisão por Singh et al. (2010) a fibronectina é considerada uma das proteínas que auxiliam o alinhamento de fibras colágenas, enquanto Kubo et al. (2000) consideram que fibronectina estimula a diferenciação dos adipócitos. Estudos com doenças fibróticas relatam que no processo de fibrose existe a produção excessiva, deposição e contração da matriz extracelular e níveis elevados de proteínas, incluindo colágeno e fibronectina (LEASK; ABRAHAM, 2004). Nossos resultados evidenciam o aumento significativo da expressão gênica da fibronectina, no entanto, quanto à imunopositividade, houve um aumento na presença da proteína no grupo TC comparado com C, contudo mais discreto em relação ao colágeno VI.

Durante o processo de diferenciação a fibronectina é a primeira proteína a ser expressa, e ao longo do processo que sua síntese é diminuída, sendo pouco expressa em adipócitos maduros (KUBO et al., 2000). No entanto, no desenvolvimento do processo de fibrose o conteúdo de fibronectina é aumentado, bem como, a deposição de matriz. Singh et al. (2010) relatam a presença excessiva de fibronectina em doenças fibróticas, tais como glomeropatias, doença renal e quelóides.

Interessantemente, o remodelamento tecidual é um conjunto de múltiplos processos que variam de acordo com estímulo inicial, mas que necessita da ocorrência de dois eventos: a síntese e deposição de componentes da MEC, e a quebra proteolítica. Entre as proteases implicadas na degradação da MEC encontram-se as MMPs (STAMENKOVIC, 2003). Contudo, em nosso estudo foi demonstrado que a expressão gênica, assim como a imunohistoquímica para MMP2 estão reduzidas nos pacientes caquéticos, embora não fora avaliada a atividade da enzima. No estudo de Freise et al. (2009), os autores demonstraram que o aumento do colágeno tipo $\mathrm{VI}$, em especial da cadeia $\alpha 2$, contribui para diminuição da MMP2, por esse sequestrar a forma inativa da MMP2 e ainda, modulando sua atividade, portanto bloqueando a atividade proteolítica. Apesar dos autores demonstrarem a especificidade da cadeia $\alpha 2$, não podemos deixar de mencionar novamente que para tecido adiposo, segundo Mariman e Wang (2010), todas as alfas cadeias do colágeno tipo VI são necessárias para sua estabilidade, e assim podemos especular que a molécula do colágeno VI em nosso estudo pode ter contribuído para a diminuição da MMP2.

O tecido adiposo possui características ímpares e uma enorme versatilidade, sendo dessa forma, podemos especular a respeito do seu verdadeiro papel frente à caquexia, ora 
agindo como uma vítima passiva, ou ainda, contribuindo efetivamente para evolução irreversível da caquexia. 


\section{CONCLUSÃO}

A perda de tecido adiposo na caquexia do câncer é acompanhada por mudanças nos componentes da matriz extracelular que levam a perda das características morfológicas e o surgimento de fibrose tecidual. A MEC possui características que são especialmente importantes para a manutenção da biologia do adipócito. Entre os componentes da MEC que foram analisados, o colágeno tipo VI parece ser o maior contribuinte para o desenvolvimento da atrofia adiposa, além de exercer papel na regulação da matriz extracelular de tecido adiposo observadas na caquexia associada ao câncer. 


\section{REFERÊNCIAS*}

AGUSTSSON, T.; RYDÉN, M.; HOFFSTEDT, J.; HARMELEN, V. V.; DICKER, A.; LAURENCIKIENE, J.; ISAKSSON, B.; PERMERT, J.; ARNER, P. Mechanism of increased lipolysis in cancer cachexia. Cancer Res., v. 67, n. 11, p. 5531-5537, 2007.

ARGILÉS, J. M.; OLIVAN, M.; BUSQUETS, S.; LÓPEZ-SORIANO, F. J. Optimal management of cancer anorexia-cachexia syndrome. Review. Cancer Management and Research, v. 2, p. 2738, 2010.

ARGILÉS, J. S.; LOPEZ-SORIANO, F.; BUSQUETS, S. Novel approaches to the treatment of cachexia. Drug. Discovery Today, v. 13, n. 1-2, p. 73, 2008.

ARGILÉS, J. M.; BUSQUETS, S.; LÓPEZ-SORIANO, F. J. Cytokines in the pathogenesis of cancer cachexia. Curr. Opin. Clin. Nutr. Metab. Care, v. 6, n. 4, p. 401-406, 2003. Review.

BEN-NOUN, L. L. The disease that caused weight loss in King David the Great. J. Gerontol. A. Biol. Sci. Med. Sci., v. 59, p. 143-145, 2004.

BENNANI-BAITI, N.; WALSH, D. What is cancer anorexia-cachexia syndrome? A historical perspective. J. R. Coll. Physicians Edinb., v. 39, p. 257-262, 2009.

BERTEVELLO, P.; SEELAENDER, M. Heterogeneous response of adipose tissue to cancer cachexia. Braz. J. Med. Biol. Res., v. 34, n. 9, p. 1161-1167, 2001.

BEN-NOUN, L. L. The disease that caused weight loss in King David the Great. J. Gerontol. A. Biol. Sci. Med., v. 59, p. 143- 145, 2004.

BING, C.; TRAYHURN, P. New insights into adipose tissue atrophy in cancer cachexia. Proc. Nutr. Soc., v.68, p.385-392, 2009.

BING, C.; RUSSEL, S.; BECKET, E.; POPE, M.; TISDALE, M. J.; TRAYHURN, P.; JENKINS, J. R. Adipose atrophy in cancer cachexia: morphologic and molecular analysis of tissue in tumourbearing mice. Br. J. Cancer, v. 95, p. 1028- 1037, 2006.

BING, C.; BROWN, M.; KING, P.; COLLINS, P.; TISDALE, M. J.; WILLIAMS, G. Increased gene expression of brown fat uncoupling protein (UCP)1 and skeletal muscle UCP2 and UCP3 in MAC16-induced cancer cachexia. Cancer Res., v. 60, p. 2405-2410, 2000.

BOULOUMIÉ, A.; SENGENÈS, C.; PORTOLAN, G.; GALITIZKY, J.; LAFONTAN, M. Adipocyte produces matrix metalloproteinases 2 and 9, Involvement in adipose differentiation. Diabetes, v. 50, p. 2080- 2086, 2001.

BRUERA, E.; SWEENEY, C. Cachexia and asthenia in cancer patients. Lancel. Oncol., v. 1, p. 138-147, 2000.

*De acordo com: ASSOCIAÇÃO BRASILEIRA DE NORMAS TÉCNICAS. NBR 6023: informação e documentação: referências: elaboração. Rio de Janeiro, 2002. 
CHAKRABORTI, S.; MANDAL, M.; DAS, S.; MANDAL, A.; CHAKRABORTI, T. Regulation of matrix metalloproteinases. Mol. Cell. Biochem., v. 349, p. 269- 285, 2003.

DAHLMAN, I.; MEJHERT, N.; LINDER, K.; AGUSTSSON, T.; MUTCH, D. M.; KULYTE, A.; ISAKSSON, B.; PERMERT, J.; PETROVIC, N.; NEDERGAARD, J.; SJÖLIN, E.; CLEMENT, K.; DAHLMAN-WRIGHT, K.; RYDÉN, M.; ARNER, P. Adipose tissue pathways involved in weight loss of cancer cachexia. Br. J. Cancer, p. 1-8, 2010.

DENG, Y.; SCHERER, P. Adipokines as novel biomarkers and regulators of the metabolic syndrome. Ann. N.Y. Acad. Sci., v. 1212, p. E-1-E-19, 2010.

DIVOUX, A.; CLÉMENT, K. Architecture and the extracellular matrix: the still unappreciated components of the adipose tissue. Obesity Reviews, v. 12, p. e494- e503, 2011.

EVANS, J. W. et al. Cachexia: A new definition. Clinical Nutrition, v. 27, p. 793- 799, 2008.

FEARON, K.; STRASSER, F.; ANKER, S. D.; BOSAEUS, I.; BRUERA, E.; FAINSINGER, R. L.; JATOI, A.; LOPRINZI, C.; MacDONALD, N.; MANTOVANI, G.; DAVIS, M.; MUSCARITOLI, M.; OTTERY, F.; RADBRUCH, L.; RAVASCO, P.; WALSH, D.; WILCOCK, A.; BARACOS, V. E. Definition and classification of cancer cachexia: an international consensus. Lancet. Oncol., v. 12, p. 489495, 2011.

FLIERS, E.; KREIER, F.; VOSHOL, P. J.; HAVEKES, L. M.; SAUERWEIN, H. P.; KALSBEEK, A.; BUIJS, R. M.; ROMIJN, J. A. White adipose tissue: Getting nervous. J. Neuroendocrinol., v. 15, p. 1005-1010, 2003.

FONSECA-ALANIZ, M.H.; TAKADA, J.; ALONSO-VALE, M.I.; LIMA, F.B. The adipose tissue as a regulatory center of the metabolism. Arq. Bras. Endocrinol. Metabol., v. 50, n. 2, p. 216-229, 2006.

FOX, K. M.; BROOKS, J. M.; GANDRA, S. R.; MARKUS, R.; CHIOU, C. F. Estimation of Cachexia among Cancer Patients Based on Four Definitions. J. Oncol., v. 2009, p. 1-7, 2009.

FREISE, C.; ERBEN, U.; MUCHE, M.; FARNDALE, R.; ZEITZ, M.; SOMASUNDARAM, R.; RUEHL, $M$. The alpha 2 chain of collagen type $\mathrm{VI}$ sequesters latente proforms of matrixmetalloproteinases and modulates their activation and activity. Matrix Biology, v. 28, p. 480489, 2009.

GELSE, K.; PÖSCHL, E.; AIGNER, T. Collagens- structure, function, and biosynthesis. Advanced Drug Delivery Reviews, v. 55, p. 1531- 1546, 2003.

HALBERG, N.; WERNSTED-ASTERHOLM, I.; SCHERER, P. E. The adipocyte as an endocrine cell. Endocrinol. Metab. Clin. N. Am., v. 37, p. 753- 768, 2008.

HAUNER, H. The new concept of adipose tissue function. Physiol. Behav., v. 83, p. 653-658, 2004. 
HENEGAR, C.; TORDJMAN, J.; ACHARD, V.; LACASA, D.; CREMER, I.; GUERRE-MILLO, M.; POITOU, C.; BASDEVANT, A.; STICH, V.; VIGUERIE, N.; LANGIN, D.; BEDOSSA, P.; ZUCKER, J. D.; CLEMENT, K. Adipose tissue transcriptomic signature highlights the pathological relevance of extracellular matrix in human obesity. Genome Biology, v. 9, p. R14, 2008.

INTERNATIONAL AGENCY OF RESEARCH IN CANCER. Handbooks of cancer prevention. Weight Control and Physical Activity, v. 6, p. 237-356, 2002.

KATZ, A. M.; KATZ, P. B. Diseases of the heart in the works of Hippokrates. Br. Heart J., v. 24, p. 257-64, 1962.

KEOPHIPHATH, M.; ACHARD, V.; HENEGAR, C.; ROUAULT, C.; CLÉMENT, K.; LACASA, D. Macrophage-secreted factors promote a profibrotic phenotipe in human preadipocytes. Mol. Endocrinol., v. 23, n. 1, p. 11-24, 2009.

KHAN, T.; MUISE, E. S.; IYENGAR, P.; WANG, Z. V.; CHANDALIA, M.; ABATE, N.; ZHANG, B. B.; BONALDO, P.; CHUA, S.; SCHERER, P. E. Metabolic Dysregulation and Adipose Tissue fibrosis: role of Collagen VI. Mol. Cell. Biol., v. 29, n. 6, p. 1575-1591, 2009.

KUBO, Y.; KAIDZU, S.; NAKAJIMA, I.; TAKENOUCHI, K.; NAKAMURA, F. Organization of extracellular matrix components during differentiation of adipocytes in long-term culture. In Vitro Cell. Dev. Biol., v. 36, p. 38- 44, 2000.

LAVIANO, A.; MEGUID, M. M.; INUI, A.; MUSCARITOLI, M.; ROSSI-FANELLI, F. Therapy insight: Cancer anorexia-cachexia syndrome--when all you can eat is yourself. Nat. Clin. Pract. Oncol., v. 2, n. 3, p. 158-165, 2005.

LAVIANO, A.; MEGUID, M. M.; ROSSI-FANELLI, F. Cancer anorexia: clinical implications, pathogenesis, and therapeutic strategies. Lancet. Oncol. v. 4, n. 11, p. 686-694, 2003.

LEASK, A.; ABRAHAM, D. J. TGF-B signaling and the fibrotic response. FASEB Journal, v. 18, p. 816-827, 2004.

LIRA, F. S.; ROSA, J. C.; YAMASHITA, A. S.; KOYAMA, C. H.; BATISTA Jr. M. L.; SEELAENDER, M. C. L. Endurance training induces depot-specific changes in IL-10/TNF $\alpha$ ratio in rat adipose tissue. Cytokine, v. 45, p. 80-85, 2009.

MACHADO, A.; COSTA ROSA, L.; SEELAENDER, M. Adipose tissue in Walker 256 tumourinduced cachexia: possible association between decreased leptin concentration and mononuclear cell infiltration. Cell. Tissue Res., v. 318, n. 3, p. 503-514, 2004.

MARIMAN, E. C. M.; WANG, P. Adipocyte extracellular matrix composition, dynamics and role in obesity. Cell Mol. Life Sci., v. 66, p. 1277-1292, 2010.

MORLEY, J. E.; THOMAS, D. R.; WILSON, M. G. Cachexia: pathophysiology and clinical relevance. Am. J. Clin. Nutr., v. 83, p. 735-743, 2006. 
MURPHY, R. A.; WILKE, M. S.; PERRINE, M.; PAWLOWICZ, M.; MOURTZAKIS, M.; LIEFFERS, J. R.; MANESHGAR, M.; BRUERA, E.; CLANDININ, M. T.; BARACOS, V. E.; MAZURAK. Loss of adipose tissue and plasma phospholipids: Relationship to survival in advanced cancer patients. Clinical Nutrition, v. 29, p. 482-487, 2010.

MYLLYHARJU, J.; KIVIRIKKO, K. I. Collagens, modifying enzymes and their mutations in humans, flies and worms. Trends in Genetics, v. 20, p. 33, 2003.

NAKAJIMA, I.; YAMAGUCHI, T.; OZUTSUMI, K.; ASO, H. Adipose tissue estracellular matrix: newly organized by adipocytes during differentiation. Differentation, v. 63, p. 193-200, 1998.

NAPOLITANO, L. The diffentiation of white adipose cells, an electron microscope study. J. Cell. Biol., v. 42, p. 663-679, 1963.

PAGE-McCAW, A.; EWALD, A. J.; WERB, Z. Matrix Metalloproteinases and the regulation of tissue remodeling. Nat. Rev. Mol. Cell Biol., v. 8, p. 221, 2007.

PASARICA, M.; GOWRONSKA-KOSAK, B.; BURK, D.; REMEDIOS, I.; HYMEL, D.; GIMBLE J.; RAVUSSIN, E.; BRAY, G.A.; SMITH,S.R. Adipose tissue Collagen VI in obesity. J. Clin. Endocrin. Metab., v. 94, n. 12, p. 5155-5162, 2009.

PIERLONI, C.; VERDENELLI, F.; CASTELLUCCI, M.; CINTI, S. Fibronectins and basal lamina molecules expression in human subcutaneous white adipose tissue. Eur. J. Histochem., v. 42, p. 183-188, 1998.

POND, C. M. Physiological specialisation of adipose tissue. Progress in Lipid Research, v. 38, p. 225-248, 1999.

POND, C. M. Paracrine interactions of mammalian adipose tissue. J. Exp. Zoolog. A. Comp. Exp. Biol., v. 295, n. 1, p. 99- 110, 2003.

PUCHTLER, H.; MELOAN, S. N.; WALDROP, F. S. Are picro-dye reactions for collagens quantitative? Chemical and histochemical considerations. Histochemistry, v. 88, p. 243-256, 1988.

RICARD-BLUM, S.; RUGGIERO, F. The collagen superfamily: from the extracellular matrix to the cell membrane. Pathologie Biologie, v. 53, p. 430-442, 2005.

ROUBENOFF, R.; HEYMSFIELD, S. B.; KEHAYIAS, J. J. et al. Standardization of nomenclature of body composition in weight loss. Am. J. Clin. Nutr., v. 66, p. 192-196, 1997.

RYDÉN, M.; AGUSTSSON, A.; LAURENCIKIENE, J.; BRITTON, T.; SJOLIN, E.; ISAKSSON, B.; PERMERT, J.; ARNER, P. Lypolysis- Not inflammation, cell death, or lipogenesis- Is involved in adipose tissue loss in cancer cachexia. Cancer, v. 113, n. 7, p. 1695- 1704, 2008. 
SEELAENDER, M. C. L.; OLLER DO NASCIMENTO, C. M.; CURI, R.; WILLIAMS, J.F. Studies on the lipid metabolism of walker 256 tumor-bearing rats during the development cancer cachexia. Biochem. Mol. Biol. Int., v. 39, n. 5, p. 1037- 1047, 1996.

SINGH, P.; CARRAHER, C.; SCHWARZBAUER, J.E. Assembly of fibronectin extracellular matrix. Annu. Rev. Cell Dev. Biol., v. 26, p. 397-419, 2010.

SMITH, S. R. The endocrinology of obesity. Endocrinol. Metab. Clin. North. Am., v. 25, p. 921-942, 1996.

SOCIETY ON CACHEXIA AND WASTING DISORDERS. 1a Cachexia Conference. 2000. Disponível em: <http://www.cachexia.org>. Acesso em: 5 mar. 2010.

SPENCER, M.; YAO-BORENGASSER, A.; UNAL, R.; RASOULI, N.; GURLEY, C.M.; ZHU, B.; PETERSON, C. A.; KERN, P. A. Adipose tissue macrophages in insulin-resistant subjects are associated with collagen $\mathrm{VI}$ and fibrosis and demonstrate alternative activation. Am. J. Physiol. Endocrinol. Metab., v. 299, p. E1016-E1027,2010.

STAMENKOVIC, I. Extracellular matrix remodeling: the role of matrix metalloproteinases. J. Pathol., v. 200, p. 448- 464, 2003.

TILG, H.; MOSCHEN, R. Adipokines: mediators linking adipose tissue, inflammation and immunity. Nat. Rev. Immunol., v. 6, p. 772, 2006.

TISDALE, M. J. Caquexia in cancer patients. Nat. Rev. Cancer, v. 2, p. 862- 871, 2002.

TRAYHURN, P.; BEATTIE, J. H. Physiological role of tissue: white adipose tissue as an endocrine and secretory organ. Proc. Nutr. Soc., v. 60, p. 329-339, 2001.

ZHANG, Y.; PROENCA, R.; MAFFEI, M.; BARONE, M.; LEOPOLD, L.; FRIEDMAN, J.M. Positional cloning of the mouse obese gene and its human homologue. Nature, v. 372, p. 425-432, 1994.

WANG, P.; MARIMAN, E.; RENES, J.; KEIJER, J. The secretory function of adipocytes in the physiology of white adipose tissue. J. Cell. Physiol., v. 216, p. 3-13, 2008.

WANG, H.; EDENS, N. K. mRNA and lipolytic role of phosphodiesterase 4 in rat adipocytes in vitro. J. Lipid. Res., v. 48, p. 1099-1107, 2007. 
ANEXO A

Consentimento Livre e Esclarecido 
TERMO DE CONSENTIMENTO LIVRE E ESCLARECIDO

ESTUDO: Influência das Citocinas pró e anti-inflamatórias no tecido adiposo branco. Possivel interação adipócito e infiltrado mononuclear.

Você está sendo convidado (a) a participar do projeto de pesquisa acima citado. 0 documento abaixo contém todas as informações necessárias sobre a pesquisa que estamos fazendo. Sua colaboração neste estudo será de muita importância para nós, mas se desistir a qualquer momento, isso não causará nenhum prejuizo a você.

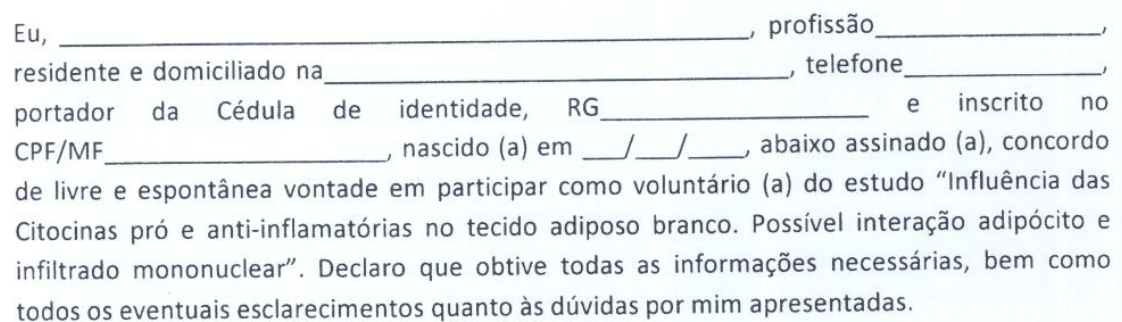

Estou ciente que:

1) O estudo se faz necessário para que se possam descobrir as possiveis causas da síndrome denominada caquexia (síndrome caracterizada pela grande perda de peso, força muscular e diminuição do apetite) associada ao câncer. Será utilizado o sangue e o tecido adiposo branco para as análises. Esses materiais coletados demonstram-se importantes para o entendimento da etiologia do processo de caquexia. A pesquisa terá duração total de quatro anos, sendo sua participação pontual, ou seja, apenas no ato cirúrgico;

2) Será feita uma coleta de $20 \mathrm{ml}$ de sangue, no momento da entrevista e consentimento da participação do projeto, por um profissional da saúde;

3) Essa coleta será feita apenas para este estudo, em nada influenciará o tratamento e não modificará o procedimento cirúrgico;

4) Durante o procedimento cirúrgico será retirado um fragmento de aproximadamente um grama de tecido adiposo branco subcutâneo de omento, com tempo total de coleta de aproximadamente 5 minutos. Esse procedimento possui um grau de risco mínimo, não interferindo nos procedimentos padrões da cirurgia;

5) Essa coleta será feira apenas para este estudo e em nada influenciará o tratamento; não vai me curar, não vai me causar nenhum problema, não haverá nenhum incômodo de dor no momento da coleta; 
6) A participação neste projeto não tem objetivo de me submeter a um tratamento, bem como não me acarretará qualquer despesa pecuniário com relação aos procedimentos médico-clínico-terapêuticos efetuados com o estudo;

7) Tenho a liberdade de desistir ou de interromper a colaboração neste estudo no momento em que desejar, sem necessidade de qualquer explicação;

8) A desistência não causará nenhum prejuizo à minha saúde ou bem estar físico. Não virá interferir no atendimento ou tratamento médico;

9) Os resultados obtidos durante este ensaio serão mantidos em sigilo, mas concordo que sejam divulgados em publicações científicas, desde que meus dados pessoais não sejam mensionados;

10) Casou eu desejar, poderei pessoalmente tomar conhecimentos dos resultados, ao final desta pesquisa.

( ) Desejo conhecer os resultados desta pesquisa.

( ) Não desejo conhecer os resultados desta pesquisa.

11) Concordo que o material poderá ser utilizado em outros projetos desde que autorizado pela Comissão de Ética deste Instituto e pelo responsável por esta pesquisa.

( ) Sim ou ( ) Não

"DEClaro Que, APÓS CONVENIENTEMENTE ESCLARECIDO PELO PESQUisador E TER ENTENDIDO O QUE ME FOI EXPLICADO, CONSINTO EM PARTICIPAR DA PRESENTE PESQUISA".

São Paulo, de 2011.

( ) Paciente / ( ) Responsável:

Testemunha 1:

Nome / RG / Telefone

Testemunha 2:

Nome / RG / Telefone

Responsável pelo Projeto:

Prof. Dra. Marilia Cerqueira Leite Seelaender Instituto de Ciências Biomédicas I

Telefone para contato: 30917225

Identificação do CEP-HU: Endereço: Av. Prof. Lineu Preste, 2565 - Cidade Universitária CEP: 05508-900 São Paulo - SP

Telefone: 3039-9457 ou 3039-9479

e-mail: CEP@hu.usp.br 
ANEXO B

Questionários 
PROJETO MEDICINA BASEADA EM EVIDÊNCIAS CA-HU

\section{AVALIACÃO MÉDICA}

RH:

DADOS DE IDENTIFICAÇÃO DO PACIENTE:

Nome:

Telefone:

Idade:

Sexo: (F) (M)

Profissão:

Altura:

Peso:

IMC:

CASO:

ClassificaÇão: (CA COM CAQUeXia) (CA SEM CAQUeXia) (CAQUeXia SEM TUMOR) (CONTROLE)

PERDA > 10\% NOS ULTIMOS 6 MESES: (SIM) (NÃO)

RELAÇĀO CINTURA QUADRIL:

EXAMES (data):
\begin{tabular}{|c|c|c|c|c|c|}
\hline $\begin{array}{c}\text { Aval. } \\
\text { Laboratorial }\end{array}$ & Resultado Exames & $\begin{array}{c}\text { Aval. } \\
\text { Laboratorial }\end{array}$ & Resultado Exames & $\begin{array}{c}\text { Aval. } \\
\text { Laboratorial }\end{array}$ & Resultado Exames \\
\hline HG & & Glicose & & Creatinina & \\
\hline PCR & & Colesterol & & Uréia & \\
\hline Albumina & & Triglicérides & & & \\
\hline
\end{tabular}

FÁRMACOS EM USO:

\begin{tabular}{|c|c|c|c|}
\hline FARMACOS EM USO: & Freqüência e dose & $\begin{array}{c}\text { Há quanto } \\
\text { tempo }\end{array}$ & Motivo \\
\hline Medicamento & & & \\
\hline & & & \\
\hline
\end{tabular}


CASCO

A)Questões

Durante a ultima semana:

1-Sentiu-se limitado no seu emprego ou no desempenho de suas atividades diárias:
Não Um pouco
Um pouco Bastante
Muito

2-Custa-lhe fazer esforços mais violentos, por exemplo,carregar um saco de compras pesado ou uma mala

Não $\quad$ Um pouco $\quad$ Bastante Muito

3-Tem percebido uma diminuição da força de preensão manual

Não Um pouco Bastante $\quad$ Muito

4-Você precisa fazer um esforço maior que o comum ao subir escadas?

Não Um pouco Bastante Muito

5-Custa-lhe dar um pequeno passeio a pé,fora de casa,aproximadamente $1 \mathrm{~km}$ ?

Não Um pouco Bastante

Muito

B)Questionário de Anorexia

1-Meu apetite esta:

a)Muito ruim

b)Ruim

c)Mais ou menos

d)Bom

e)Muito bom

2-Quando eu como:

a) Eu me sinto cheio depois de comer pouco

b) Eu me sinto cheio depois de comer um terço da comida

c)Eu me sinto cheio depois de comer meia refeição

d)Eu me sinto cheio depois de comer mais da metade da refeição

e)

3-O sabor dos alimentos:

a)Muito ruim

b) Ruim

c)Mais ou menos

d)Bom

e)Muito bom

4-Normalmente eu como:

a)Menos de uma refeição ao dia

b)Uma refeição ao dia

c)Duas refeições ao dia

d)Três refeições ao dia

e)Mais que três refeições ao dia

C)Questionário de Qualidade de Vida

1)Durante o dia você precisa ficar na cama ou na cadeira?

Não Um pouco Bastante Muito

2)Precisa que o ajudem a comer,vestir-se lavar-se ou ir ao banheiro

Não Um pouco Bastante

Muito

$\begin{array}{lll}\text { 3) Sentiu-se limitado no seu emprego ou no desempenho das suas atividades diárias } & \text { Bastante } \\ \text { Um pouco } & \text { Muito }\end{array}$

Não Sentiu-se limitado na ocupação habitual dos seus tempos livres ou noutras atividades de lase

Não Um pouco Bastante

5) Teve falta de ar:

Não Um pouco Bastante Muito 


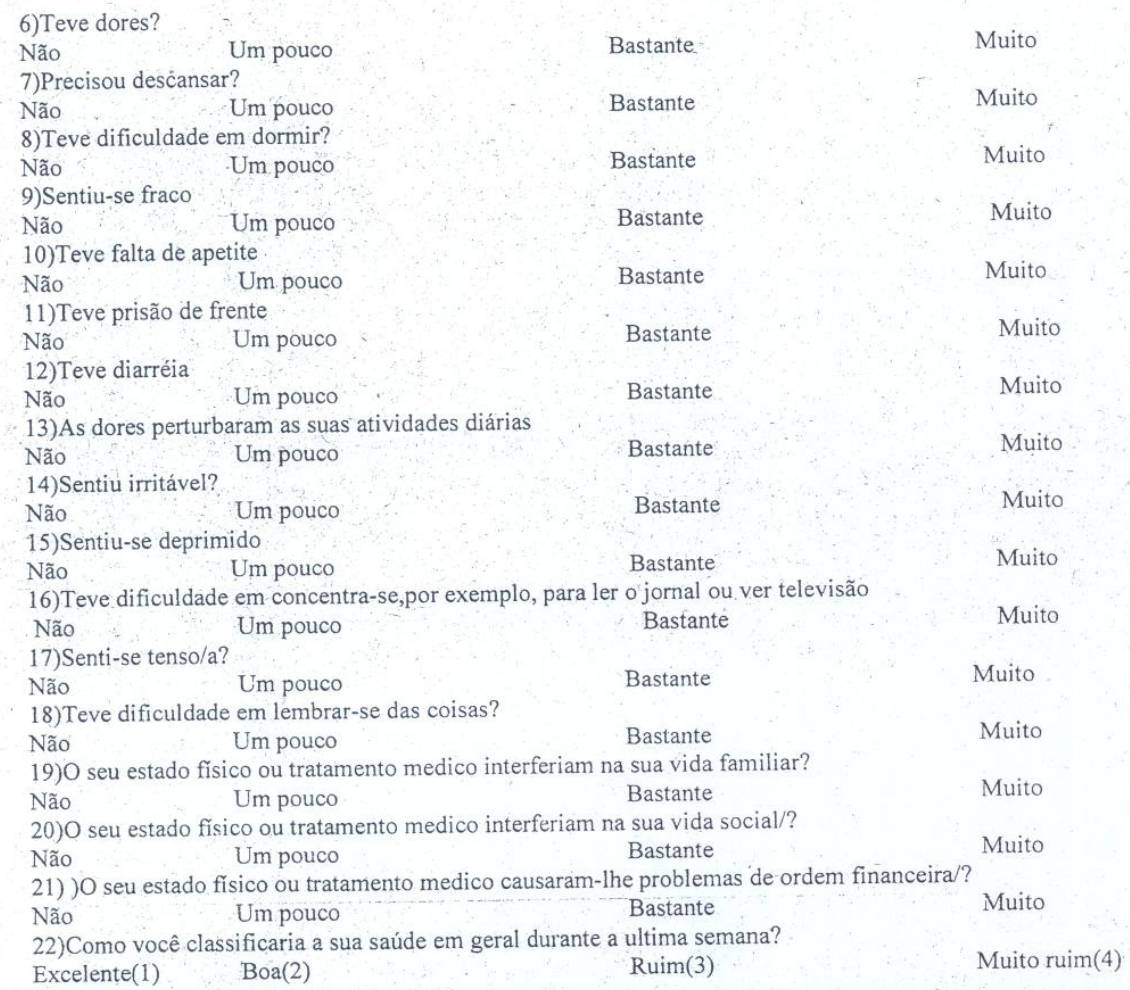


Nome e Sobrenome

Sexo Data de Nascimento

Tipo de Neoplasia

Estadiamento Terapia Precedente (Cirurgia/Radio/Quimio)

Comorbidade Primeira Visita

Perda de Peso (S/N) Tamanho da Perda de peso ( $\%$ nos últimos 3 meses)

Peso (na hospitalização) Altura IMC

Como está seu apetite no último mês?

Aumentado Normal Diminuido

Quantidade ingerida no almoço do dia anterior? $\quad 100 \% \quad 75 \% \quad 50 \% \quad 25 \% \quad 0 \%$

\section{Pontuacão Anoréxica}

\begin{tabular}{|l|c|c|c|c|c|}
\hline & Nada & Um pouco & Moderadamente & Bastante & Muito \\
\hline Meu apetite é bom? & 0 & 1 & 2 & 3 & 4 \\
\hline A quantidade que eu como me satisfaz? & 0 & 1 & 2 & 3 & 4 \\
\hline Me preocupo com meu peso? & 0 & 1 & 2 & 3 & 4 \\
\hline Os alimentos têm um gosto ruim? & 4 & 3 & 2 & 1 & 0 \\
\hline Estou preocupado por parecer magro? & 4 & 3 & 2 & 1 & 0 \\
\hline Meu apetite acaba no inicio das refeições? & 4 & 3 & 2 & 1 & 0 \\
\hline Há dificuldade de comer alimentos pesados ou elaborados? & 4 & 3 & 2 & 1 & 0 \\
\hline Minha familia me induz a comer? & 4 & 3 & 2 & 1 & 0 \\
\hline Vômitos? & 4 & 3 & 2 & 1 & 0 \\
\hline Mes sinto satisfeito após algumas mordidas? & 4 & 3 & 2 & 1 & 0 \\
\hline Dores no estômago? & 4 & 3 & 2 & 1 & 0 \\
\hline Minha saude está melhorando? & 0 & 1 & 2 & 3 & 4 \\
\hline
\end{tabular}

Total de Pontos:

\section{Questionario anorexia}

Saciedade Precoce? Anorexia:

\section{Escala análoga Visual}

$$
\text { Saciado } 0
$$

$\mathrm{Cm}$ :
Visita de controle (3 meses)
Peso
IMC ...........
Terapia realizada (Cirurgia/Radio/Quimio)
Complicações 